\title{
Irradiation Performance of HTGR Fuel Rods in HFIR Experiments HT-26 and -27
}

\author{
T. N. Tiegs \\ A. J. Caputo \\ E. L. Long, Jr. \\ B. H. Montgomery
}

\section{OAK RIDGE NATIONAL LABORATORY}

OPERATED BY UNION CARBIDE CORPORATION FOR THE ENERGY RESEARCH AND DEVELOPMENT ADMINISTRATION 


\section{DISCLAIMER}

This report was prepared as an account of work sponsored by an agency of the United States Government. Neither the United States Government nor any agency Thereof, nor any of their employees, makes any warranty, express or implied, or assumes any legal liability or responsibility for the accuracy, completeness, or usefulness of any information, apparatus, product, or process disclosed, or represents that its use would not infringe privately owned rights. Reference herein to any specific commercial product, process, or service by trade name, trademark, manufacturer, or otherwise does not necessarily constitute or imply its endorsement, recommendation, or favoring by the United States Government or any agency thereof. The views and opinions of authors expressed herein do not necessarily state or reflect those of the United States Government or any agency thereof. 


\section{DISCLAIMER}

Portions of this document may be illegible in electronic image products. Images are produced from the best available original document. 
Printed in the United States of America. Available from

National Technical Information Service

U.S. Department of Commerce

5285 Port Royal Road, Springfield, Virginia 22161

Price: Printed Copy $\$ 4.50 ;$ Microfiche $\$ 2.25$

4.2

This report was prepared as an account of work sponsored by the United States Government. Neither the United States nor the Energy Research and Development Administration/United States Nuclear Regulatory Commission, nor any of their employees, nor any of their contractors, subcontractors, or their employees, makes any warranty, express or implied, or assumes any legal liability or responsibility for the accuracy, completeness or usefulness of any information, apparatus, product or process disclosed, or represents that its use would not infringe privately owned rights. 
ORNL/TM-5404

UC-77 (Gas-Cooled

Reactor Technology)

\author{
Contract No. W-7405-eng-26 \\ METALS AND CERAMICS DIVISION \\ HTGR BASE TECHNOLOGY PROGRAM
}

Fueled Graphite Development (189a OHOO2)

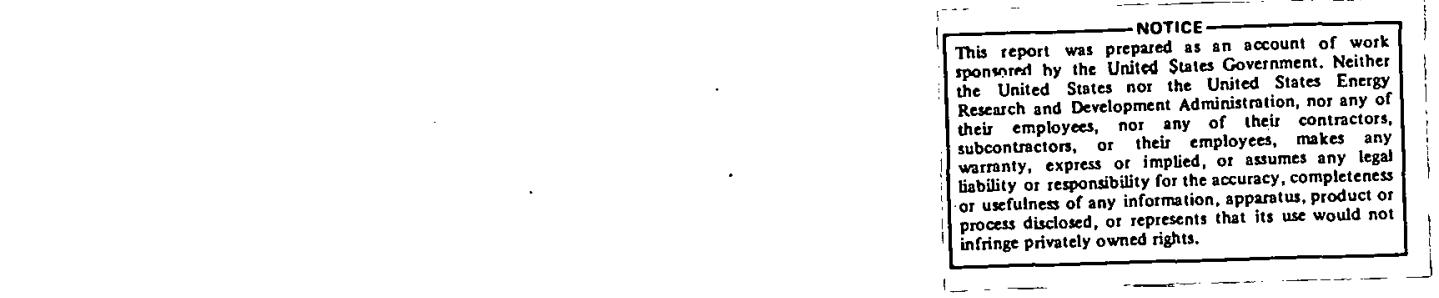

IRRADIATION PERFORMANCE OF HTGR FUEL RODS IN

HFIR EXPERIMENTS HT-26 AND -27

T. N. Tiegs, A. J. Caputo, E. L. Long, Jr., and B. H. Montgomery

AUGUST 1976

OAK RIDGE NATIONAL LABORATORY

Oak Ridge, Tennessee 37830

operated by

UNION CARBIDE CORPORATION

for the

ENERGY RESEARCH AND DEVELOPMENT ADMINISTRATION

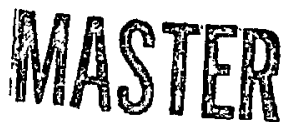

OT $W-7405-E N G-26$

DISTRIBUTION IE THIS DOCUMEIVT IS UNLIMITED 
THIS PAGE

WAS INTENTIONALLY

LEFT BLANK 
CONTENTS

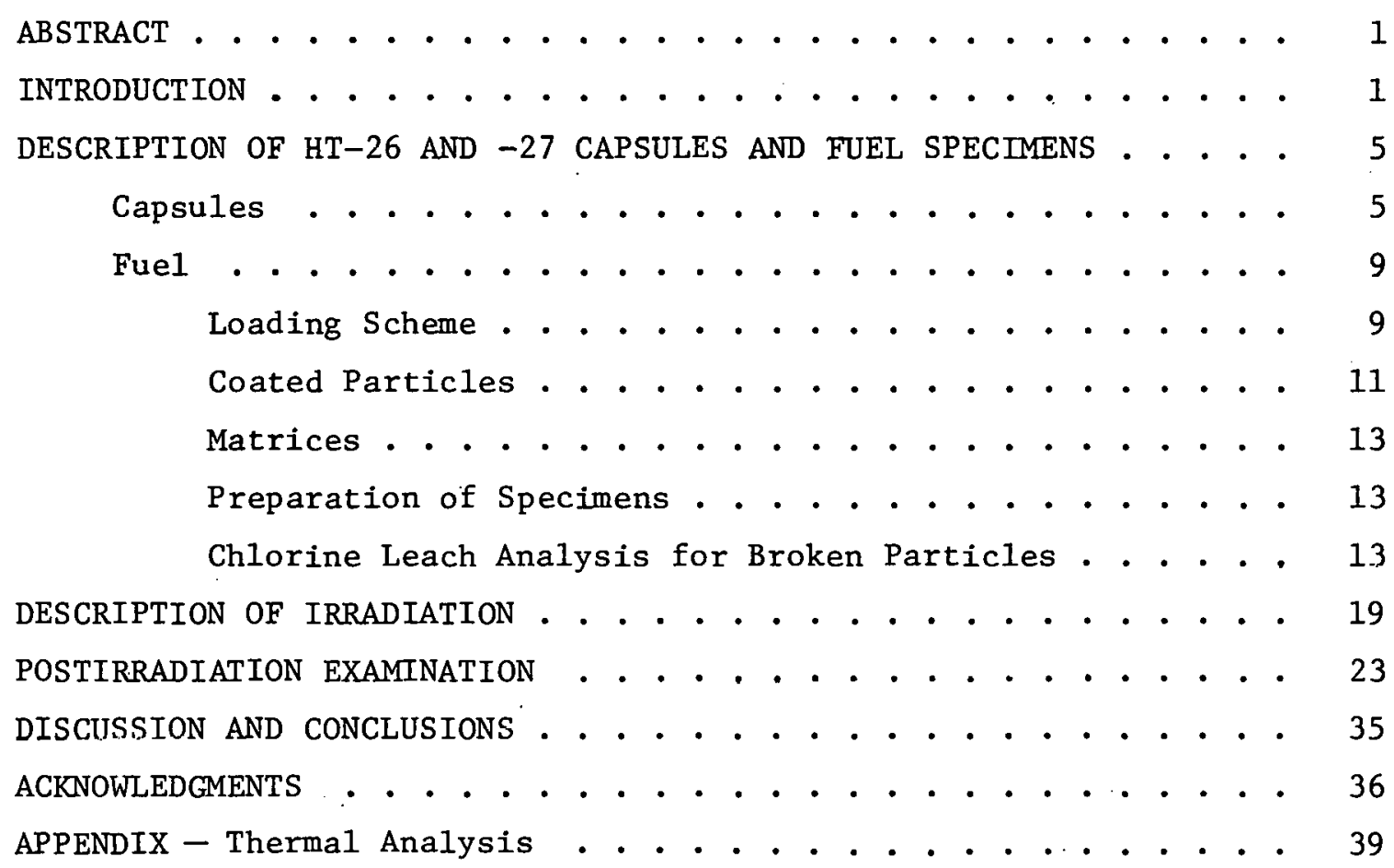


IRRADIATION PERFORMANCE OF HTGR FUEL RODS IN HFIR EXPERIMENTS HT -26 AND -27

T. N. Tiegs, A. J. Caputo, E. L. Long, Jr., and $\mathrm{B}$. H. Montgomery

\begin{abstract}
Capsules HT-26 and -27 were irradiated in the target region of the High Flux Isotope Reactor. The purpose was to study matrix-particle interaction in High-Temperature Gas-Cooled Reactor fuel rods before and after irradiation. The first objective was to fabricate fuel with a failed fuel fraction $<0.1 \%$. This was accomplished for packed $\mathrm{Al}_{2} \mathrm{O}_{3}$ and in-block carbonization techniques, using annealed Biso-coated fertile particles and either annealed or unannealed Triso-coated fissile particles. The second objective, to irradiate fuel rods and determine the failed fuel fraction ( $<1 \%$ for acceptable results), was not completely accomplished. In HT-26 the capsule evidently leaked, and the fuel rods suffered attack by steam. In HT-27 the fuel rods only in the high-temperature region suffered attack by zirconium (used as an oxygen getter in the capsule). These problems resulted in failed particles and consequently made it impossible to determine failure fractions due to matrix-particle interaction. Resulte from the other fuel rods in HT-27 showed that particle failure fractions of $<1 \%$ can be obtained from fuel rods carbonized in-tube and irradiated at temperatures up to $\sim 900^{\circ} \mathrm{C}$ (fuel surface temperature).
\end{abstract}

\title{
INTRODUCTION
}

Uninstrumented test capsules HT-26 and -27 were irradiated in the target region of the High Flux Isotope Reactor (HFIK). Their purpose was to study matrix-particle interaction in High-Temperature Gas-Cooled Reactor (HTGR) fuel rods, The effect of botli matrix and fuel particle properties on matrix-particle interaction was investigated.

\footnotetext{
${ }^{1}$ Reactor Division.
} 
Fuel used in HTGRs consists of coated microspheres (or kernels) containing uranium or thorium (as fissile or fertile material respectively) in the form of oxides or carbides. The coatings consist of both porous and dense pyrolytic carbon and sometimes silicon carbide, but always with the dense pyrolytic carbon as the outermost layer. These coated particles ( 300 to $850 \mu \mathrm{m}$ in diameter) are formed into rods by injecting hot pitch and graphite filler into a bed of particles held in a mold. The volatiles from the pitch are removed by heating in a process called carbonization. Because the rods have a tendency to deform during carbonization, they are placed in packed $\mathrm{Al}_{2} \mathrm{O}_{3}$ powder or in the graphite blocks in which they will be irradiated. Since carbonization in $\mathrm{Al}_{2} \mathrm{O}_{3}$ involves powder handling operations which would be extremely difficult to perform in a remotely controlled hot-cell facility, for HTGR recycle it is essential to develop the in-block carbonization process.

The primary objective of the HT-26 and -27 experiments was to study the irradiation behavior of fuel rods carbonized in graphite tubes, which simulates the in-block carbonization technique proposed for remote refabrication. Specific objectives include:

1. fabrication of fuel rods with a failed fuel content of $<0.1 \%$;

2. irradiation of fuel rods and determination of the failed fuel content following irradiation (this number should be $<1 \%$ for acceptable results).

Previous accelerated irradiation tests ${ }^{2}$ of HTGR fuel rods have revealed a potential problem associated with an interaction between the matrix and the fuel particle coatings in rods carbonized by the propoced in-hlock carbonization technique. The HRB-4 and -5 irradiation tests showed that a rod carbonized in a graphile tube (oimulating in-block) with a high pitch-coke yleld $(-40 \%)$ and a very dense microstructure contained many broken particles after 1rradiation. On the other hand, a rod carbonized in packed $\mathrm{Al}_{2} \mathrm{O}_{3}$ powder with a low pitchcoke yield $(\sim 25 \%)$ and a very porous matrix microstructure gave acceptable irradialiui performance. A somparison of the matrix microstructures is shown in Fig. 1 .

It is hypothesized that shrinkage of the matrix during fabrication (in particular, carbonization) produces stresses which initiate tears in the particle coating and could lead to particle failure. An example of particle coating cearlug is shown in Fig. 2. Additional shrinkage

${ }^{2}$ F. J. Homan et al., Irradiation Performance of HTGR Fuel Rods in HFIR Experiments HRB-4 and -5, ORNL/TM-5115 (June 1976).

${ }^{3}$ Weight fraction of pitch plus additives remaining in the rod after carbonization. 

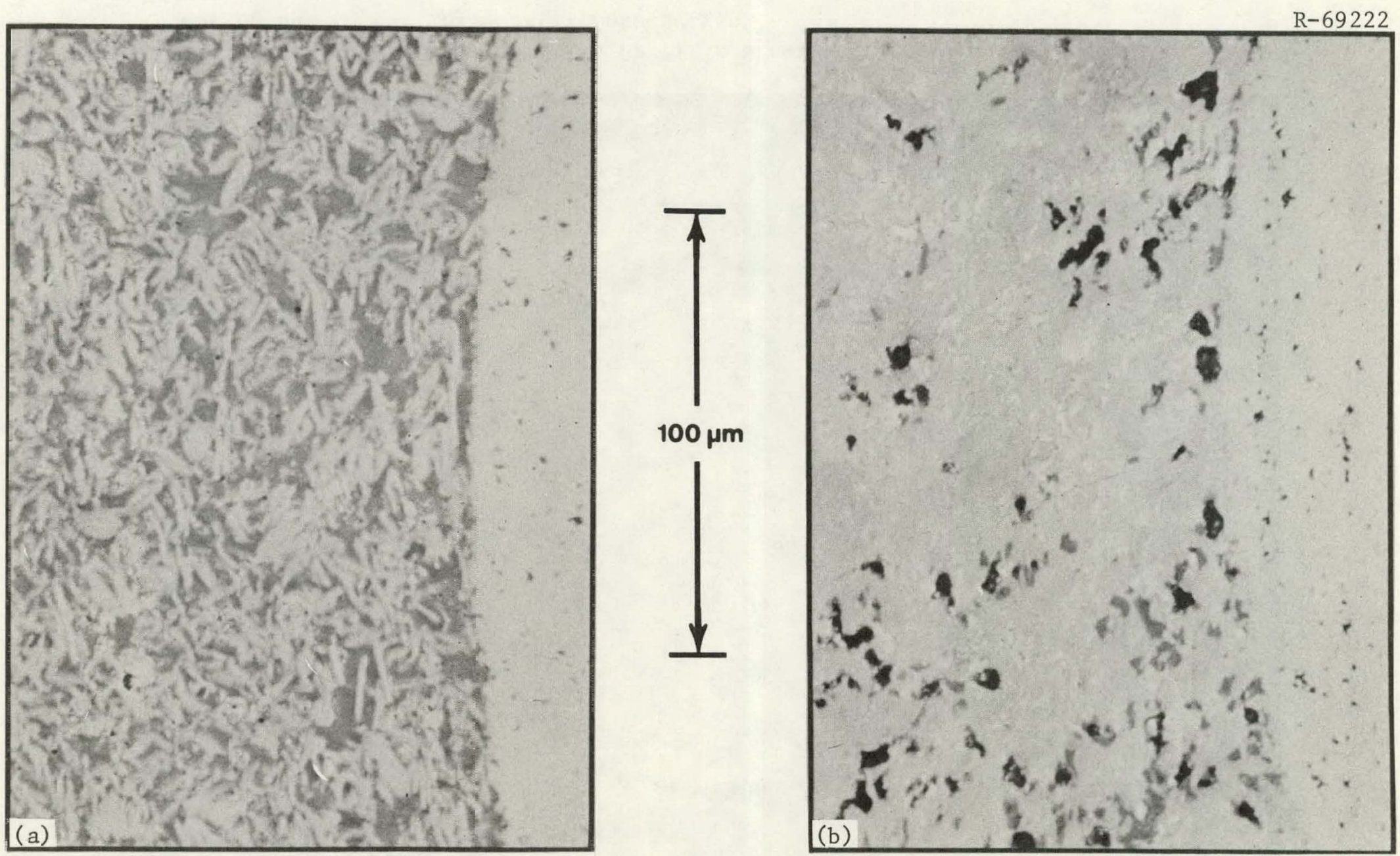

Fig. 1. Comparison of Matrix Microstructures From (a) Packed $\mathrm{Al}_{2} \mathrm{O}_{3}$ Powder and (b) In-Block Carbonization Techniques Before Irradiation. 


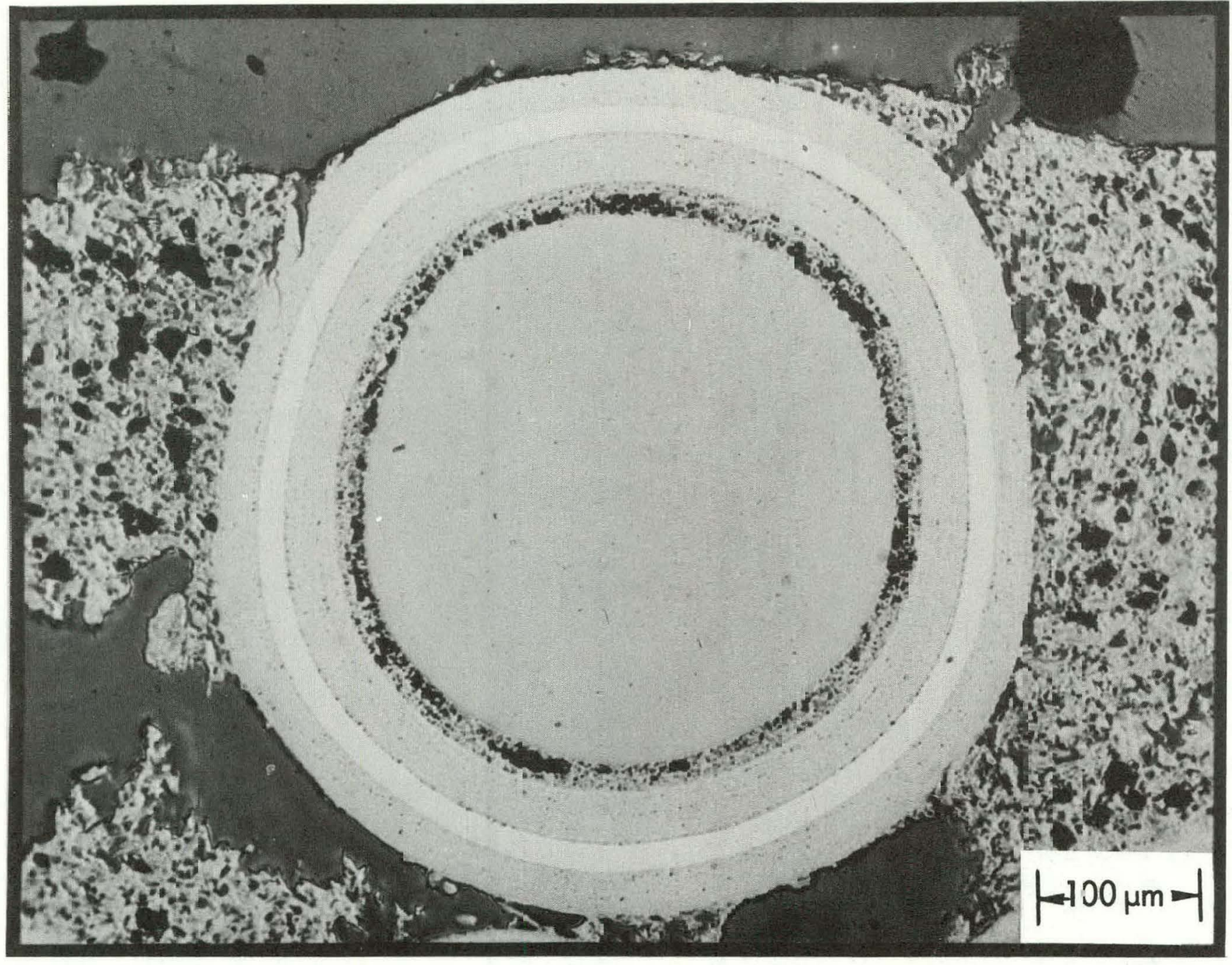

Fig. 2. Unirradiated Triso Particle Showing Teミring of Outer Isotropic Coating Due to Particle-Matrix Inceraction. 
of the matrix during irradiation causes additional particle failures as shown in Fig. 3. It is further hypothesized that the extent of matrixparticle interaction leading to particle failure is dependent on the strength of the matrix, the strength of the particles, and the strength of the matrix-particle bond. The strength of the matrix and the matrixparticle bond is related to the pitch-coke yield and the surface texture of the particles.

Recent development work has shown that the broken particle fraction in fired fuel rods is related to the pitch-coke yield of the fuel rod matrix and the mean rupture load of the coated particles. It has also been shown that the pitch-coke yield can be substantially reduced by proper selection of binders and by controlling process parameters.

In addition, the mean rupture load of Biso-coated particles can be increased by annealing. Development coating studies have shown that the surface texture of coated particles can be altered by gaseous impregnation at the end of the coating run.

The objectives of HT- 26 and -27 were fulfilled by determining the failed fuel fraction of fuel rods both before and after irradiation. This was the first test in which the failed fuel fraction was determined by means of chlorine leach analysis of fired fuel rods. Exposure of fired rods to gaseous chlorine at elevated temperatures $\left(>1000^{\circ} \mathrm{C}\right.$ ) results in the leaching of thorium or uranium because of cracked coatings. In this manner, matrix-particle interaction could be investigated and a meaningful evaluation of in-block carbonization made. It was recognized that because of the very low fuel loading required in the target region of the HFIR, this first experiment might only serve as a survey experiment.

\section{DESCRIPTION OF HT-26 AND -27 CAPSULES AND FUEL SPECIMENS}

\section{Capsules}

The exterior capsule design and containment for capsules HT-26 and -27 were identical to those of the previous capsules in the HT series, and the internal design was similar to that of capsules HT-24 and -25 . Each capsule contained 16 fuel specimens, with 4 specimens in each of the Poco graphite magazines, which were contained inside a standard aluminum irradiation capsule as shown in Fig. 4.

The capsules in the target region of the HFIR have no provision for monitoring the irradiation temperature and are sealed under an inert atmosphere. Thus, temperature control is accomplished by adjusting the initial fuel loading, the gap between the fuel specimens and the graphite sleeve, and the gap between the graphite sleeve and the aluminum capsule, as determined by the thermal analysis of the system. 

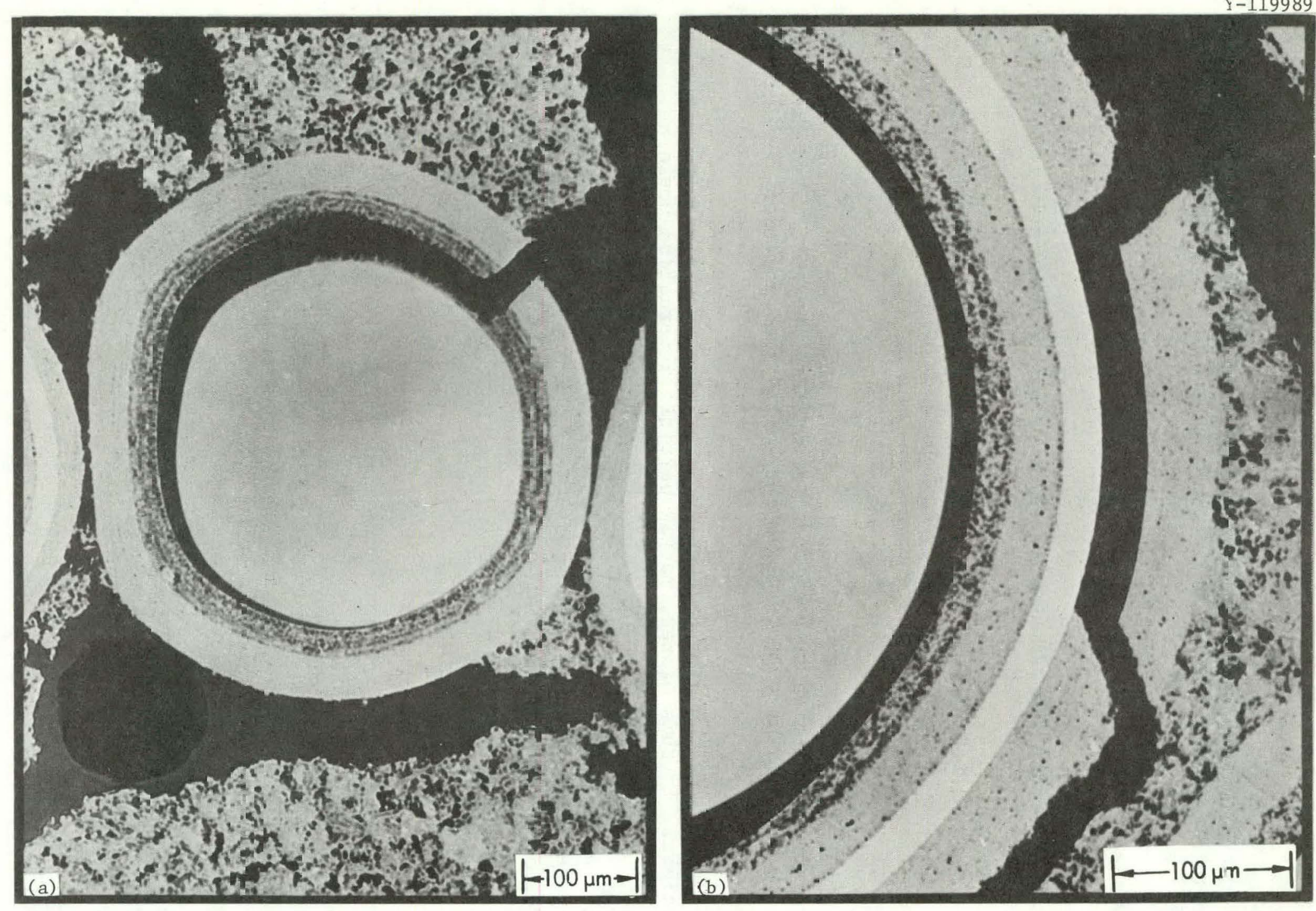

Fig. 3. Particles Broken Because of Matrix-Particle Interacticr During Irradiation. (a) Biso particle, and (b) Triso particle. 


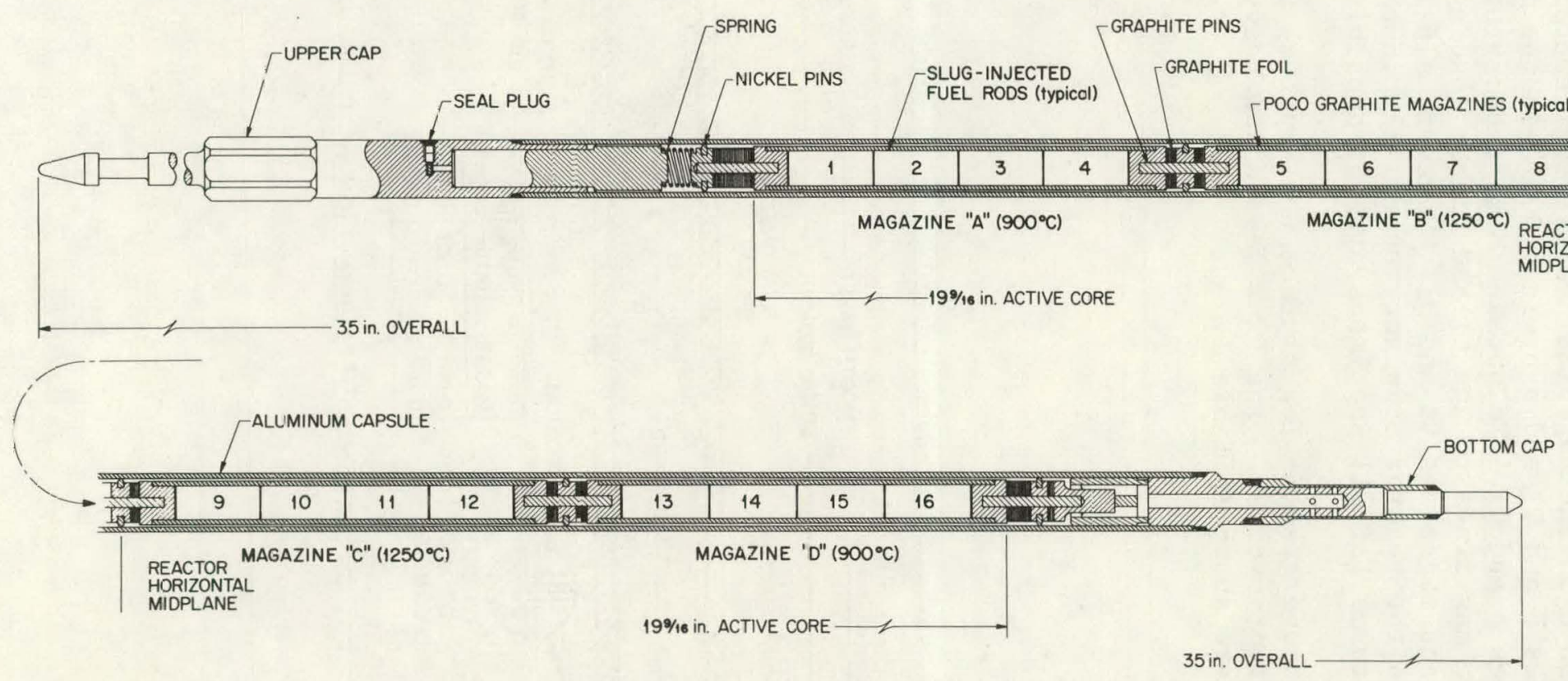

Fig. 4. HFIR Target Capsule Typical for HT-26 and -27 . 
Typical dimensions of the fuel specimens and the graphite sleeves are shown in Fig. 5. As noted, the nominal fuel specimen diameter was $0.381 \mathrm{in}$. and the nominal length was $0.93 \mathrm{in}$. This resulted in a stacked fuel length of 3.73 in. per magazine, or 14.92 in. per capsule.

The capsules were designed to have a nominal specimen surface temperature of $1250^{\circ} \mathrm{C}$ in the magazine nearest the reactor horizontal midplane (magazines $\mathrm{B}$ and $\mathrm{C}$ ) and a nominal $900^{\circ} \mathrm{C}$ in the magazine on each end (magazines $\mathrm{A}$ and $\mathrm{D}$ ). To obtain these temperatures, the specimens in the middle magazines ( $B$ and $C$ ) had higher loadings than the specimens in the end magazines ( $A$ and $D$ ). However, since flux varies with distance from the reactor midplane, especially in the end magazines, identical temperatures for all specimens are not possible.

Capsule HT-26 operated at low fluence (two cycles) and HT-27 at high fluence (four cycles). The flux levels and heavy-metal loading for the capsules are shown in Table 1.

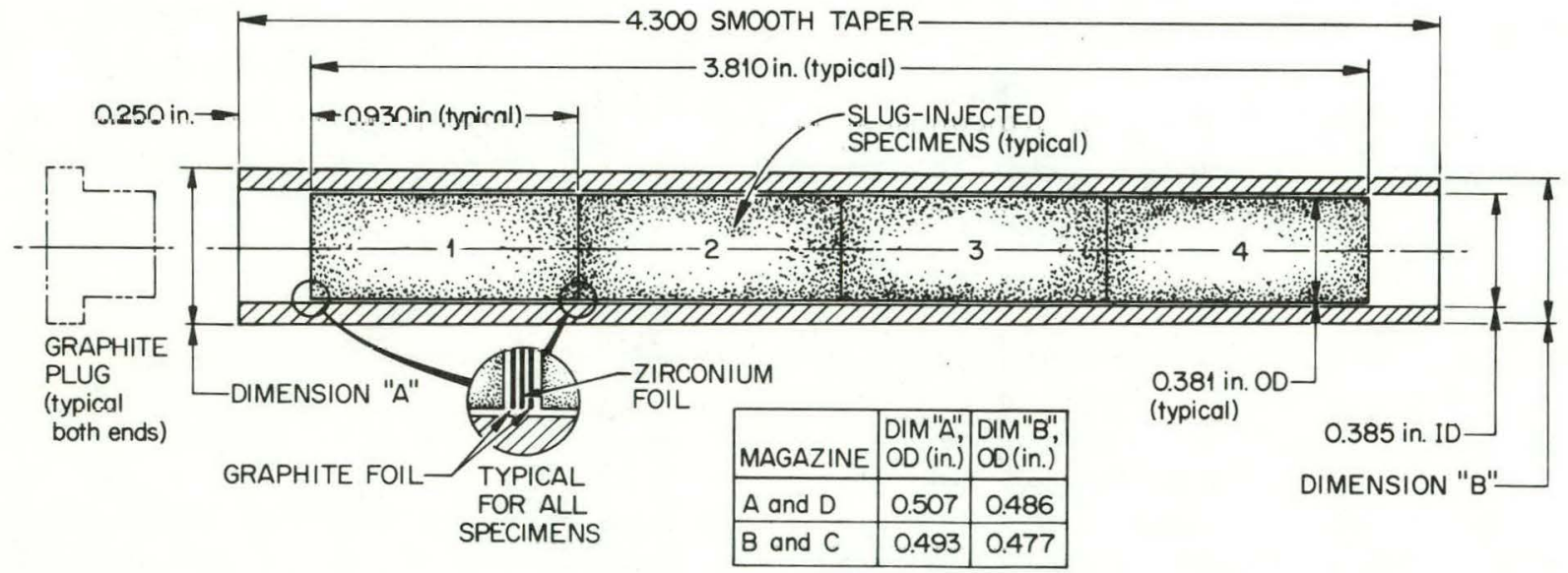

Fig. 5. Typical Magazine Configuration for HT-26 and -27 . 
Table 1. Fast-Neutron Flux and Heavy-Metal Loading for Capsules HT-26 and -27

\begin{tabular}{|c|c|c|c|c|c|c|c|}
\hline \multirow{3}{*}{$\begin{array}{l}\text { Position } \\
\text { in } \\
\text { Capsule }\end{array}$} & \multicolumn{6}{|c|}{ Heavy-Metal Loading, $\mathrm{g} / \mathrm{cm}^{3}$} & \multirow{3}{*}{$\begin{array}{c}\text { Fast-Neutron } \\
\text { F1ux } \\
E>0.18 \mathrm{MeV} \\
\left(\mathrm{n} \mathrm{cm} \mathrm{cm}^{-2} \mathrm{sec}^{-1}\right)\end{array}$} \\
\hline & \multicolumn{3}{|c|}{ HT-26 } & \multicolumn{3}{|c|}{ HT -27} & \\
\hline & ${ }^{235} \mathrm{U}$ & ${ }^{238} \mathrm{U}$ & ${ }^{232} \mathrm{Th}$ & $235 \mathrm{U}$ & ${ }^{238} \mathrm{U}$ & $232 \mathrm{Th}$ & \\
\hline (1) & 0.00084 & 0.01318 & 0.0275 & 0.00084 & 0.01321 & 0.0276 & $0.60 \times 10^{15}$ \\
\hline (2) & 0.00084 & 0.01319 & 0.0276 & 0.00084 & 0.01319 & 0.0276 & 0.71 \\
\hline (3) & 0.00083 & 0.01306 & 0.0273 & 0.00083 & 0.01302 & 0.0272 & 0.82 \\
\hline (4) & 0.00084 & 0.01315 & 0.0275 & 0.00083 & 0.01300 & 0.0272 & 0.91 \\
\hline (5) & 0.00115 & 0.01814 & 0.0381 & 0.00118 & 0.01852 & 0.0389 & 1.07 \\
\hline (6) & 0.00117 & 0.01843 & 0.0388 & 0.00116 & 0.01830 & 0.0385 & 1.11 \\
\hline$(7)$ & 0.00115 & 0.01804 & 0.0379 & 0.00116 & 0.01828 & 0.0384 & 1.15 \\
\hline (8) & 0.00117 & 0.01838 & 0.0386 & 0.00117 & 0.01841 & 0.0387 & 1.17 \\
\hline \multicolumn{8}{|l|}{$\begin{array}{l}\text { Reactor } \\
\text { Midplane }\end{array}$} \\
\hline (9) & 0.00116 & 0.01820 & 0.0383 & 0.00117 & 0.01842 & 0.0387 & 1.17 \\
\hline (10) & 0.00118 & 0.01862 & 0.0392 & 0.00118 & 0.01852 & 0.0389 & 1.15 \\
\hline (11) & 0.00117 & 0.01839 & 0.0387 & 0.00114 & 0.01797 & 0.0378 & $1 . .11$ \\
\hline (12) & 0.00116 & 0.01820 & 0.0383 & 0.00117 & 0.01843 & 0.0388 & 1.07 \\
\hline (13) & 0.00082 & 0.01281 & 0.0268 & 0.00082 & 0.01293 & 0.0270 & 0.91 \\
\hline (14) & 0.00083 & 0.01305 & 0.0273 & 0.00082 & 0.02190 & 0.0269 & 0.82 \\
\hline$(15)$ & 0.00084 & 0.01317 & 0.0275 & 0.00083 & 0.01304 & 0.0272 & 0.71 \\
\hline (16) & 0.00084 & 0.01319 & 0.0276 & 0.00085 & 0.01329 & 0.0278 & 0.60 \\
\hline
\end{tabular}

Fue1

Loading scheme

Each capsule contained 16 specimens, with all specimens made by the slug-injection process at ORNL. General Atomic Company (GAC) supplied one of the four matrix types tested. A11 the specimens were separated by a Grafoil-zirconium-Grafoil sandwich as shown in Fig. 5 . The zirconium foil was to act as an oxygen "getter," and the Grafoil was to prevent reaction of the zirconium with the specimens. However, this was the major disappointment of the test, as discussed later in this report.

Since the main purpose of the experiment was to study the matrixparticle interaction phenomenon, combinations of four matrix types and two particle types were tested. The 16 specimens per capsule permitted at least one sample of each of the eight specimen types (four matrix and two particle typcs) to be tested at each of the two capsule 
temperatures $\left(900\right.$ and $\left.1250^{\circ} \mathrm{C}\right)$. However, since the first priority was to evaluate the matrix-particle interaction, using in-block carbonization of the candidate reference matrix, these specimens were duplicated in each capsule in order to bring the total number of fuel particles subjected to postirradiation chlorine leaching into a statistically significant range. To accommodate these duplications, four other specimens were eliminated from each capsule.

The second priority was given to the GAC matrix; thus, none of these specimens were removed. Therefore, two of the four specimens of the remaining two matrix types were removed from $\mathrm{HT}-26$, and the other two specimen types were removed from HT-27. Due to the variable flux in the end magazines, specimens were positioned to optimize comparison between particle types, both within and among matrix types. The loading plan for both capsules in shown in Table 2. This identifies the specimen type in relation to the matrix, carbonization mode, pitch-coke yield, particle type, surface temperature, and specimen location in each capsule.

Table 2. Loading Plan for HT-26 and -27 Irradiation Testa to Study Matrix-Particle Interaction

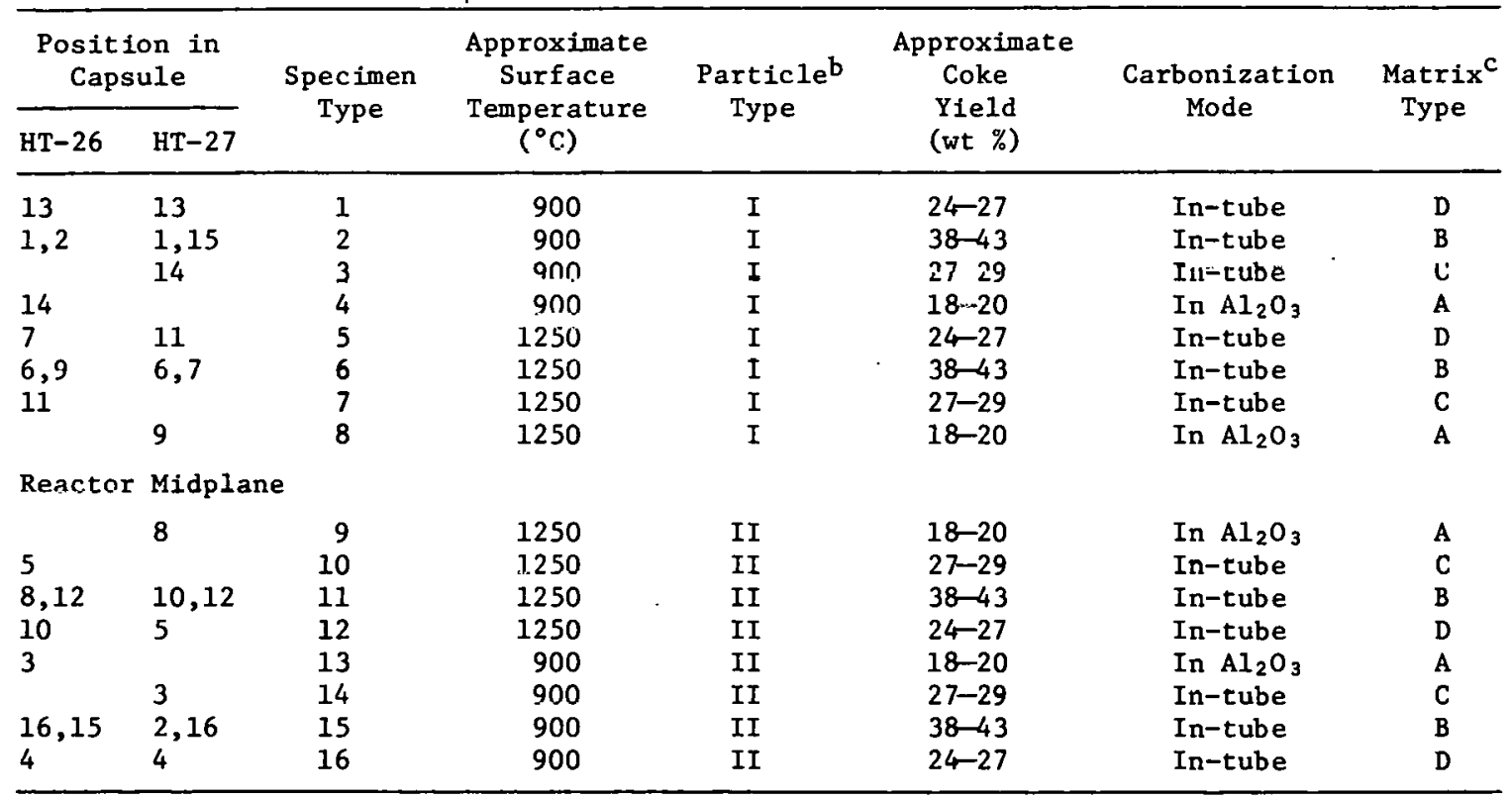

${ }^{2}$ HT-26 operated two cycles; HT-27 operated four cycles.

${ }^{b}$ Particle type I consists of Triso fissile with outer LTI deposited at $1275^{\circ} \mathrm{C}$ from $100 \%$ MAPP gas, surface treated and annealed (batch OR2248H), and Biso-coated fertiles with unannealed LTI deposited at $1350^{\circ} \mathrm{C}$ from $100 \%$ propylene (batch J-461). Particle type II consists of Triso fissiles with outer LTI deposited at $1325^{\circ} \mathrm{C}$ from $50 \%$ MAPP gas without surface treating or annealing (batch OR2249), and Biso-coated fertiles with annealed LTI deposited at $1350^{\circ} \mathrm{C}$ from $100 \%$ propylene (batch J-465). MAPP is an Airco, Inc., trade name for stabilized methylacetylene propadiene.

Matrix types are as follows: type A contains high coke yield Ashland A-240 pitch carbonized in $\mathrm{Al}_{2} \mathrm{O}_{3}$; type $\mathrm{B}$ contains Ashland $\mathrm{A}-240$ pitch carbonized in a graphite tube; type C contains low coke yield Ashland A-170 pitch carbonized in a graphite tube; type D is current GAC matrix carbonized in a graphite tube. 
Coated Particles

All specimens in the test contained fertile, fissile ( $6.5 \%$ enrichment), and carbon inert particles. Since a primary objective of the test was to evaluate fuel particles, two types of both fertile and fissile were used. The characteristics of all particles are given in Table 3 .

The primary objective of the two types of Biso-coated fertile particles was to evaluate particle strength of essentially reference design particles. The fertile kernels $\left(\mathrm{ThO}_{2}\right)$ were prepared by the solgel process, and the particles were identical through deposition of the low-temperature isotropic (LTI) coating. The type I fertile particles were used in the unannealed (as-coated) condition, but the type II fertile particles were used in the annealed (an additional heat treatment at $1800^{\circ} \mathrm{C}$ ) condition (see Table 2). Under these conditions the unannealed particles were relatively "weak," with an average crush load of $5.09 \mathrm{lb}$, whereas the annealed particles were relatively "strong," with an average crush load of $6.48 \mathrm{lb}$.

The objective in regard to the fissile particles was to evaluate not only particle strength but also the surface condition of the outer LTI coating. Among other factors, the extent to which matrix-particle interaction can lead to particle failure is dependent upon the strength of the matrix-to-particle bond. Coating studies had shown that the porosity and texture of the surface of the outer LTI coating could be altered by gaseous impregnation at the end of the coating run. Thus the fissile particles [Triso-coated weak-acid resin (WAR) $\mathrm{UC}_{x} \mathrm{O}_{y}$ ] were

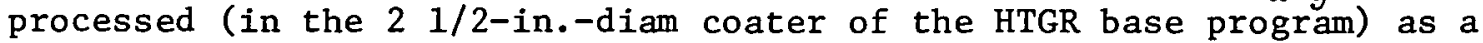
single lot through the deposition of the SiC coating. For type I fissile particles, the deposition of the outer LTI included a surface treatment at the end of the coating run followed by annealing at $1800^{\circ} \mathrm{C}$. The type II fissile particles had neither a surface treatment nor annealing (see Table 2). It was anticipated that the unannealed and annealed fissile particles would have different crush strengths, similar to the fertile particles. However, both types of particles had rather high crush strength: unannealed and not surface treated, $8.2 \mathrm{lb}$; annealed and surface treated, $7.6 \mathrm{lb}$. The SiC and the outer LTI (40 and $45 \mu \mathrm{m}$ respectively) were thicker than the present reference design ( 30 and 35 um respectively), and it appears this was a significant contribution to the high strength of both types of particles. Thus the weaker of the two types was used in fuel rods containing the "weak" fertile particles. Since evaluation (both metallographic and chlorine leach) discriminates between fissile and fertile particles, separate evaluation of the fertile and fissile particles can be made.

All specimens in the experiment contained Biso-coated inert particles. The inert carbon kernels were made from desulfurized strong-acid resin and were coated in the 2 1/2-in.-diam coater of the HTGR base program. 
Table 3. Characterization of Coated Particles for HT-26 and $-27^{a}$

\begin{tabular}{|c|c|c|c|c|c|c|}
\hline & \multicolumn{6}{|c|}{ Batch Number } \\
\hline & OR -2249 & $\mathrm{OR}-2248 \mathrm{H}$ & $J-461$ & $\mathrm{~J}-465$ & OR-2239H & $\mathrm{OR}-2240 \mathrm{H}$ \\
\hline \multicolumn{7}{|l|}{ Coated particle } \\
\hline Annealed & No & Yes & No & Yes & Yes & Yes \\
\hline Crush strength, lb & $8.22 \pm 0.89$ & $7.57 \pm 0.97$ & $5.09 \pm 0.99$ & $6.48 \pm 0.80$ & $\mathrm{ND}$ & ND \\
\hline Kernel material & $\mathrm{WAR} \cdot \mathrm{UC}_{x} \mathrm{O}_{y}$ & $\mathrm{WAR} \cdot \mathrm{UC}_{x} \mathrm{O}_{y}$ & $\mathrm{ThO}_{2}$ & $\mathrm{ThO}_{2}$ & SAR carbon & SAR carbon \\
\hline Uranium content, wt $\%$ & 16.79 & 15.76 & $\mathrm{NA}$ & NA & NA & NA \\
\hline${ }^{2{ }^{35} \mathrm{U}}$ enrichment, at. \% & 6.53 & 6.53 & NA & NA & NA & NA \\
\hline Thorium content, wt \% & NA & NA & 56.43 & 56.52 & NA & NA \\
\hline \multicolumn{7}{|l|}{ Kernel. } \\
\hline $\begin{array}{l}\text { Diameter, } \mu \mathrm{m} \\
\text { Density, } \mathrm{g} / \mathrm{cm}^{3}\end{array}$ & $\begin{array}{l}422.6 \pm 33.9 \\
2.87^{c}\end{array}$ & $\begin{array}{l}422 . \epsilon \pm 33.9 \\
2.87 \mathrm{C}\end{array}$ & $\begin{array}{l}497.8 \pm 3.8 \\
9.91\end{array}$ & $\begin{array}{l}497.1 \pm 3.2 \\
9.91\end{array}$ & $\begin{array}{l}478.0 \pm 33.4 \\
1.34^{c}\end{array}$ & $\begin{array}{l}478.0 \pm 33.4 \\
1.34 c\end{array}$ \\
\hline \multicolumn{7}{|l|}{ Buffer } \\
\hline $\begin{array}{l}\text { Thickness, } \mu \mathrm{m} \\
\text { Density, } \mathrm{g} / \mathrm{cm}^{3}\end{array}$ & $\begin{array}{l}55.1 \pm 11.1 \\
1.12^{c}\end{array}$ & $\begin{array}{l}55.1 \pm 11.1 \\
1.12^{\mathrm{c}}\end{array}$ & $\begin{array}{l}81.0 \pm 9.6 \\
1.106 / 1.263^{d}\end{array}$ & $\begin{array}{l}83.9 \pm 12.1 \\
1.106 / 1.257^{d}\end{array}$ & $\begin{array}{l}73.5 \pm N D \\
1.03^{C}\end{array}$ & $\begin{array}{l}73.5 \pm N D \\
1.03^{c}\end{array}$ \\
\hline \multicolumn{7}{|l|}{ Inner carbon } \\
\hline Thickness, $\mu \mathrm{m}$ & $40.7 \pm 4.8$ & $40.7 \pm 4.8$ & NA & NA & NA & NA \\
\hline Density, $\mathrm{g} / \mathrm{cm}^{3}$ & $1.934 \pm 0.008$ & $1.934 \pm 0.008$ & NA & NA & NA & NA \\
\hline \multicolumn{7}{|l|}{$\mathrm{SiC}$} \\
\hline Thickness, $\mu \mathrm{m}$ & $38.9 \pm 1.7$ & $38.9 \pm 1.7$ & NA & NA & NA & NA \\
\hline Density, $\mathrm{g} / \mathrm{cm}^{3}$ & ND & $\mathrm{ND}$ & $\mathrm{NA}$ & NA & NA & NA \\
\hline \multicolumn{7}{|l|}{ Outer carbon } \\
\hline Thickness, $\mu \mathrm{m}$ & $43.4 \pm 3.5$ & $46.8 \pm 3.3$ & $80.5 \pm 8.1$ & $77.7 \pm 8.0$ & $95.4 \pm 5.7$ & $97.7 \pm 6.6$ \\
\hline Density, $\mathrm{g} / \mathrm{cm}^{3}$ & $1.820 \pm 0.008$ & $2.020 \pm 0.005$ & $1.934 / 1.833^{\mathrm{e}}$ & $1.979 / 1.882^{\mathrm{e}}$ & $1.970 \pm 0.006$ & $1.958 \pm 0.005$ \\
\hline Surface treated & No & Yes & No & No & No & No \\
\hline
\end{tabular}

Where applicable, values are mean \pm standard deviation.

$\mathrm{b}_{\mathrm{NA}}=$ not applicable; $\mathrm{ND}=$ not determined.

$\dot{c}_{\text {From tapped volume. }}$

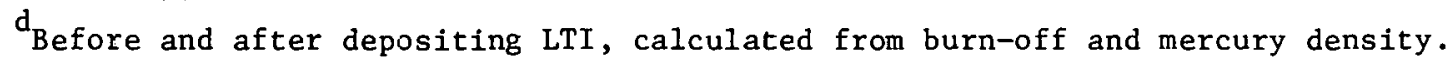

ebserved gradient/corrected gradient. 


\section{Matrices}

In addition to other factors, the extent of matrix-particle interaction is related to the pitch-coke yield of the matrix. Pitch shrinks during carbonization, and at the higher pitch-coke yields there is more carbonization and thus more shrinkage, which increases the possibility of the shrinkage on the surface of the particles and thus the possibility of breaking the coating. The experiment used four matrices to investigate pitch-coke yields ranging from approximately 18 to $43 \%$. High coke yields ( $43 \%)$ were obtained by using a matrix containing Ashland A-240 pitch carbonized in graphite tubes. Low coke yields were obtained from the other three matrices by:

1. in-powder $\left(\mathrm{Al}_{2} \mathrm{O}_{3}\right)$ carbonization using Ashland $\mathrm{A}-240$ pitch,

2. in-tube carbonization using a low-coke-yield pitch (Ashland A-170),

3. in-tube carbonization of a matrix developed by GAC (MO-357).

The composition of the various matrices is shown in Table 4 .

\section{Preparation of Specimens}

All of the specimens were prepared by the slug-injection process and had nominal dimensions of $0.381 \mathrm{in.}$ in diameter and $0.93 \mathrm{in}$. long. All of the specimens were injected at $1000 \mathrm{psi}$, but since the various matrices contained different pitches and had different compositions, the injection temperatures (actually mold heater temperature) of the matrices were different. As shown in Table 4, the temperatures were $130^{\circ} \mathrm{C}$ for the Ashland A-170 pitch, $140^{\circ} \mathrm{C}$ for the GAC matrix, and $180^{\circ} \mathrm{C}$ for the Ashland A-240 pitch.

Although all the specimens were carbonized at $800^{\circ} \mathrm{C}$, different heating rates were used for the different matrices, since both the desired coke yield and carbonization mode were different. As shown in Table 4, the specimens were either packed vertically in $\mathrm{Al}_{2} \mathrm{O}_{3}$ powder or horizontally in a graphite tube and heated at rates from 3 to $10^{\circ} \mathrm{C} / \mathrm{min}$.

All of the specimens were heat treated at $1800^{\circ} \mathrm{C}$ for $30 \mathrm{~min}$ to stabilize the matrix. Specimens were characterized by coke yield, dimensions, visual inspection, radiography, and metallography. A sumnary of this characterization data is shown in Tables 5 and 6 .

\section{Chlorine Leach Analysis for Broken Particles}

Because of the small number of fuel particles (80 to 400$)$ contained in the test specimens, the failure of a single particle would result in a failure fraction much higher than the desired $1 \times 10^{-3}$. Therefore, chlorine leach tests for broken particles were conducted on rods containing either all fissile or all fertile particles that were fabricated along with the irradiation test specimens. As mentioned previously, both types of fissile particles (unannealed and not surface treated, and annealed and surface treated) had comparable and rather high crush strength, 
Table 4. Fabrication History of Specimens for HT-26 and -27

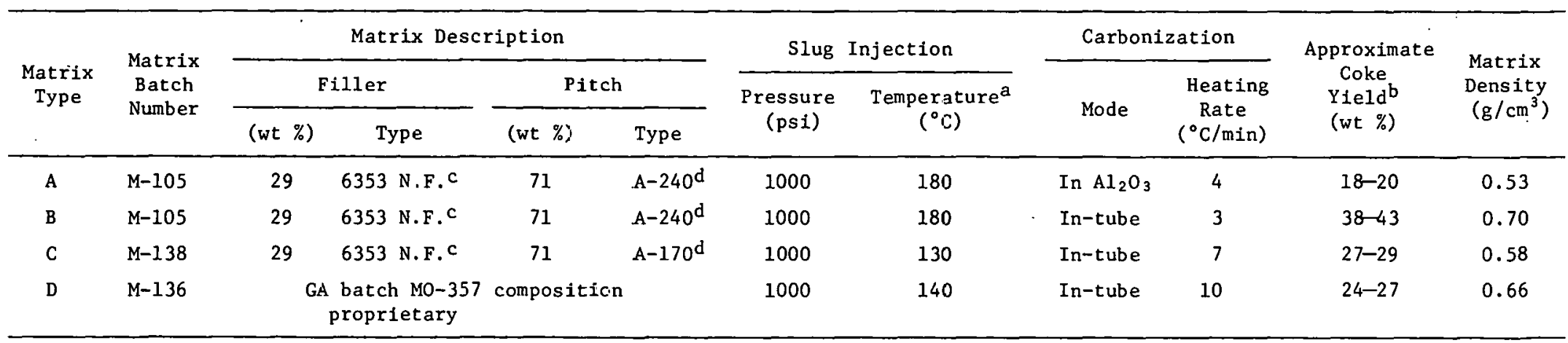

actually mold heater temperature.

${ }^{b}$ Coke yield $=\frac{\text { fired rod weight }- \text { (coated particle weight }+ \text { filler weight) }}{\text { green rod pitch weight }+ \text { additives }} \times 100$.

Asbury Mills.

dAshland 0 il. 
Table 5. Characterization of Specimens for $\mathrm{HT}-26^{\mathrm{a}}$

\begin{tabular}{|c|c|c|c|c|c|c|c|c|c|c|c|}
\hline \multirow{2}{*}{$\begin{array}{l}\text { Capsule } \\
\text { Position }\end{array}$} & \multirow{2}{*}{$\begin{array}{l}\text { Specimen } \\
\text { Number }\end{array}$} & \multirow{2}{*}{$\begin{array}{l}\text { Specimen } \\
\text { Type }^{b}\end{array}$} & \multirow{2}{*}{$\begin{array}{c}\text { Average } \\
\text { Diameter } \\
\text { (in.) }\end{array}$} & \multirow{2}{*}{$\begin{array}{c}\text { Average } \\
\text { Length } \\
\text { (in.) }\end{array}$} & \multirow{2}{*}{$\begin{array}{l}\text { Volume } \\
\left(\mathrm{cm}^{3}\right)\end{array}$} & \multirow{2}{*}{$\begin{array}{l}\text { Weight } \\
\text { (g) }\end{array}$} & \multicolumn{2}{|c|}{ Density, $\mathrm{g} / \mathrm{cm}^{3}$} & \multirow{2}{*}{$\begin{array}{c}\text { Particle } \\
\text { Volume } \\
\text { Loading } \\
(\%)\end{array}$} & \multirow{2}{*}{$\begin{array}{c}\text { Coke } \\
\text { Yield } \\
(\%)\end{array}$} & \multirow{2}{*}{$\begin{array}{c}\text { Metallo } \\
\text { graphic } \\
\text { Mount } \\
\text { Number }\end{array}$} \\
\hline & & & & & & & Matrix & Total & & & \\
\hline 1 & $M-105-656$ & 2 & 0.3795 & 0.9283 & 1.7206 & 2.220 & 0.71 & 1.290 & 58.6 & 40.8 & 79119 \\
\hline 2 & $M-105-660$ & 2 & 0.3797 & 0.9273 & 1.7206 & 2.209 & 0.70 & 1.284 & 58.2 & 42.0 & 79119 \\
\hline 3 & $M-105-649$ & 13 & 0.3823 & 0.9238 & 1.7377 & 2.122 & 0.54 & 1.221 & 58.5 & 19.4 & 79130 \\
\hline 4 & $M-136-56$ & 16 & $c .3835$ & 0.9113 & 1.7249 & 2.187 & 0.67 & 1.268 & 57.7 & 26.4 & 79133 \\
\hline 5 & $M-138-96$ & 10 & 0.3816 & 0.9360 & 1.7542 & 2.168 & 0.96 & 1.263 & 57.8 & 28.0 & 79127 \\
\hline 6 & $M-105-668$ & 6 & C. 3810 & 0.9241 & 1.7264 & 2.241 & 0.69 & 1.298 & 58.0 & 41.0 & 79123 \\
\hline 7 & $M-136-42$ & 5 & C. 3830 & 0.9345 & 1.7642 & 2.262 & 0.65 & 1.282 & 57.8 & 24.1 & 79122 \\
\hline 8 & $M-105-678$ & 11 & C. 3797 & 0.9329 & 1.7310 & 2.247 & 0.71 & 1.298 & 57.7 & 42.5 & 79128 \\
\hline 9 & $M-105-664$ & 6 & c. 3804 & 0.9388 & 1.7484 & 2.272 & 0.70 & 1.299 & 58.1 & 39.7 & 79123 \\
\hline 10 & $M-136-52$ & 12 & c. 3812 & 0.9137 & 1.7088 & 2.220 & 0.68 & 1.299 & 58.3 & 27.1 & 79129 \\
\hline 11 & $M-138-92$ & 7 & 0.3813 & 0.9248 & 1.7305 & 2.169 & 0.58 & 1.254 & 58.2 & 28.4 & 79124 \\
\hline 12 & $M-105-679$ & 11 & 0.3802 & 0.9399 & 1.7486 & 2.241 & 0.68 & 1.282 & 57.1 & 41.5 & 79128 \\
\hline 13 & $M-136-38$ & 1 & 0.3826 & 0.9401 & 1.7711 & 2.230 & 0.65 & 1.259 & 57.3 & 24.9 & 79118 \\
\hline 14 & $M-105-618$ & 4 & 0.3825 & 0.9230 & 1.7380 & 2.110 & 0.54 & 1.214 & 57.7 & 20.2 & 79121 \\
\hline 15 & $M-105-685$ & 15 & 0.3807 & 0.9236 & 1.7228 & 2.178 & 0.71 & 1.264 & 56.2 & 41.5 & 79132 \\
\hline 16 & $M-105-68 L$ & 15 & 0.3807 & 0.9223 & 1.7203 & 2.155 & 0.68 & 1.253 & 56.2 & 41.7 & 79132 \\
\hline
\end{tabular}

${ }^{\text {a }}$ Photographs 2786-74 and 2793-74 apply to all specimens.

bee Táble 2 for description. 
Table 6. Characterization of Specimens for HT $-27^{a}$

\begin{tabular}{|c|c|c|c|c|c|c|c|c|c|c|c|}
\hline \multirow{2}{*}{$\begin{array}{l}\text { Capsule } \\
\text { Position }\end{array}$} & \multirow{2}{*}{$\begin{array}{l}\text { Specimen } \\
\text { Number }\end{array}$} & \multirow{2}{*}{$\begin{array}{l}\text { Specimen } \\
\text { Type }^{b}\end{array}$} & \multirow{2}{*}{$\begin{array}{l}\text { Average } \\
\text { Diameter } \\
\text { (in.) }\end{array}$} & \multirow{2}{*}{$\begin{array}{c}\text { Average } \\
\text { Leng th } \\
(\because n .)\end{array}$} & \multirow{2}{*}{$\begin{array}{c}\text { Volume } \\
\left(\mathrm{cm}^{3}\right)\end{array}$} & \multirow{2}{*}{$\begin{array}{l}\text { Weight } \\
(\mathrm{g})\end{array}$} & \multicolumn{2}{|c|}{ Density, $\mathrm{g} / \mathrm{cm}^{3}$} & \multirow{2}{*}{$\begin{array}{c}\text { Particle } \\
\text { Volume } \\
\text { Loading } \\
(\%)\end{array}$} & \multirow{2}{*}{$\begin{array}{c}\text { Coke } \\
\text { Yield } \\
(\%)\end{array}$} & \multirow{2}{*}{$\begin{array}{l}\text { Metallo- } \\
\text { graphic } \\
\text { Mount } \\
\text { Number }\end{array}$} \\
\hline & & & & & & & Matrix & Total & & & \\
\hline 1 & $M-105-662$ & 2 & 0.3791 & 0.9287 & 1.7177 & 2.205 & 0.69 & 1.284 & 58.7 & 40.7 & 79119 \\
\hline 2 & $M-105-687$ & 15 & 0.3802 & 0.9243 & 1.7195 & 2.168 & 0.70 & 1.261 & 56.3 & 43.1 & 79132 \\
\hline 3 & $M-138-109$ & 14 & 0.3821 & 0.9273 & 1.7425 & 2.123 & 0.58 & 1.219 & 57.3 & 28.9 & 79131 \\
\hline 4 & $M-136-57$ & 16 & 0.3835 & 0.3221 & 1.7454 & 2.197 & 0.66 & 1.259 & 57.1 & 27.0 & 79133 \\
\hline 5 & $M-136-53$ & 12 & 0.3817 & 0.7165 & 1.7185 & 2.220 & 0.68 & 1.292 & 58.0 & 24.6 & 79129 \\
\hline 6 & $M-105-669$ & 6 & 0.3806 & 0.7329 & 1.7392 & 2.227 & 0.66 & 1.280 & 57.5 & 38.4 & 79123 \\
\hline 7 & $M-105-670$ & 6 & 0.3808 & 0.7329 & 1.7410 & 2.245 & 0.69 & 1.289 & 57.5 & 39.9 & 79123 \\
\hline 8 & $M-105-645$ & 9 & 0.3830 & 0.7158 & 1.7289 & 2.141 & 0.52 & 1.2 .38 & 59.1 & 18.8 & 79126 \\
\hline 9 & $M-105-640$ & 8 & 0.3832 & 0.9143 & 1.7279 & 2.139 & 0.53 & 1.238 & 58.3 & 18.7 & 79125 \\
\hline 10 & $M-105-680$ & 11 & 0.3793 & 0.7280 & 1.7183 & 2.239 & 0.71 & 1.303 & 58.1 & 41.5 & 79128 \\
\hline 11 & $M-136-44$ & 5 & 0.3834 & 0.9360 & 1.7708 & 2.273 & 0.66 & 1.284 & 57.6 & 25.1 & 79122 \\
\hline 12 & $M-105-681$ & 11 & 0.3786 & 0.9358 & 1.7263 & 2.235 & 0.70 & 1.265 & 57.9 & 39.4 & 79128 \\
\hline 13 & $M-136-39$ & 1 & 0.3828 & 0.9304 & 1.7546 & 2.235 & 0.68 & 1.274 & 57.8 & 26.2 & 79118 \\
\hline 14 & $M-138-87$ & 3 & 0.3825 & 0.9342 & 1.7591 & 2.124 & 0.55 & 1.207 & 57.1 & 27.4 & 79120 \\
\hline 15 & $M-105-663$ & 2 & 0.3802 & 0.9353 & 1.7400 & 2.212 & 0.69 & 1.271 & 57.6 & 41.0 & 79119 \\
\hline 16 & $M-105-689$ & 15 & 0.3795 & 0.9211 & 1.7073 & 2.158 & 0.69 & 1.264 & 56.7 & 39.7 & 79132 \\
\hline
\end{tabular}

a Photographs 2791-74 and 2972-74 apply to all specimens.

${ }^{\mathrm{b}}$ See Table 2 for description. 
8.2 and $7.6 \mathrm{lb}$ respectively. As shown in Table 7 , this resulted in very low particle failure fractions, regardless of the matrix or pitch-coke yield: Although fuel specifications call for a failure fraction of $1 \times 10^{-3}$, it was desired to fabricate fuel with failure fractions of $<1 \times 10^{-4}$.

Table 7. Broken-Particle Analysis of Fuel-Rods ${ }^{a}$ Containing Triso-Coated WAR ${ }^{235} \mathrm{UC}_{4.86} \mathrm{O}_{1.22}$ Particles by Chlorine Leach

\begin{tabular}{|c|c|c|c|c|c|}
\hline \multirow[b]{2}{*}{$\begin{array}{l}\text { Matrix } \\
\text { Type }\end{array}$} & \multirow[b]{2}{*}{$\begin{array}{l}\text { Specimen } \\
\text { Number }\end{array}$} & \multirow[b]{2}{*}{$\begin{array}{c}\text { Carbonization } \\
\text { Mode }\end{array}$} & \multirow[b]{2}{*}{$\begin{array}{l}\text { Pitch- } \\
\text { Coke } \\
\text { Yield } \\
\text { (wt \%) }\end{array}$} & \multicolumn{2}{|c|}{ Particle Failure Fractionb } \\
\hline & & & & $\begin{array}{c}\text { Annealed and } \\
\text { Surface Treated } \\
\text { Rupture Load, } \\
7.57 \mathrm{lb}\end{array}$ & $\begin{array}{l}\text { Unannealed and Not } \\
\text { Surface Treated } \\
\text { Rupture Load, } \\
8.22 \text { lb }\end{array}$ \\
\hline \multirow[t]{2}{*}{$A^{C}$} & $M-105-622$ & $\mathrm{Al}_{2} \mathrm{O}_{3}$ & 18.7 & $0.06 \times 10^{-4}$ & \\
\hline & $M-105-625$ & $\mathrm{Al}_{2} \mathrm{O}_{3}$ & 19.5 & & $2.19 \times 10^{-4}$ \\
\hline \multirow[t]{2}{*}{$\mathrm{B}^{\mathrm{C}}$} & $M-105-696$ & In-tube & 42.5 & 0.33 & \\
\hline & $M-105-691$ & In-tube & 42.1 & & 0.12 \\
\hline \multirow[t]{2}{*}{$c^{d}$} & $M-138-116$ & In-tube & 20.7 & 0.04 & \\
\hline & $M-138-112$ & In-tube & 29.7 & & 0.03 \\
\hline \multirow[t]{2}{*}{$D^{e}$} & $M-136-64$ & In-tube & 25.4 & 0.06 & \\
\hline & $M-136-68$ & In-tube & 26.7 & & 0.05 \\
\hline
\end{tabular}

${ }^{a}$ Fuel rods contain only WAR ${ }^{235} \mathrm{UC}_{4.86} \mathrm{O}_{1.22}$ particles and rods leached with gaseous chlorine for $2 \mathrm{hr}$ at. $1500^{\circ} \mathrm{C}$.

${ }^{b}$ Grams of uranium recovered by chlorine leach per gram of uranium in rod. Desired fallure fraction was $1 \times 10^{-4}$.

$\mathrm{C}_{29}$ wt \% Asbury 6353 natural flake and 71 wt \% Ashland A-240 pitch.

$d_{29}$ wt \% Asbury 6353 natural flake and 71 wt \% Ashland A-240 pitch.

${ }^{\mathrm{e}}$ General Atomic matrix batch M0-357, composition proprietary. 
The unannealed and annealed fertile particles had a wider range of crush strength, 5.1 and $6.5 \mathrm{lb}$ respectively. As shown in Table 8 , the annealed fertile particles had a very low particle failure fraction, regardless of the matrix or pitch-coke yield. However, Table 8 shows that the unannealed fertile particles with low crush strength had the highest failure fraction $\left(\sim 50 \times 10^{-4}\right)$ when carbonized in-tube, using matrix type $B(A-240$ pitch) at a coke yield of approximately $42 \%$. The failure fraction of these particles when used with the other three matrices at lower coke yields ranged from 20 to $0.5 \times 10^{-4}$, as shown in Table 8. These data reinforce the view that fuel rods containing sufficiently strong particles can be fabricated with very low failure fractions with various matrices or level of coke yield, but with weaker particles the failure fraction can be dependent upon the fabrication process.

Table 8. Broken-Particle Analysis of Fuel Rods ${ }^{a}$ Containing Biso-Coated $\mathrm{ThO}_{2}$ Particles by Chlorine Leach

\begin{tabular}{|c|c|c|c|c|c|}
\hline \multirow[b]{2}{*}{$\begin{array}{l}\text { Matrix } \\
\text { Type }\end{array}$} & \multirow[b]{2}{*}{$\begin{array}{l}\text { Specimen } \\
\text { Number }\end{array}$} & \multirow[b]{2}{*}{$\begin{array}{l}\text { Carbonization } \\
\text { Mode }\end{array}$} & \multirow{2}{*}{$\begin{array}{l}\text { Pitch- } \\
\text { Coke } \\
\text { Yield } \\
\text { (wt \%) }\end{array}$} & \multicolumn{2}{|c|}{ Particle Failure Fraction ${ }^{b}$} \\
\hline & & & & $\begin{array}{c}\text { J-461 Unannealed } \\
\text { Crush Strength, } \\
5.091 \mathrm{~b}\end{array}$ & $\begin{array}{l}\text { J-465 Annealed } \\
\text { Crush Strength, } \\
6.47 \mathrm{lb}\end{array}$ \\
\hline \multirow[t]{4}{*}{$\mathrm{A}^{\mathrm{c}}$} & $M-105-632$ & $\mathrm{Al}_{2} \mathrm{O}_{3}$ & 16.6 & $12.2 \times 10^{-4 t}$ & \\
\hline & $M-105-633$ & $\mathrm{Al}_{2} \mathrm{O}_{3}$ & 16.7 & 21.3 & \\
\hline & $M-105-628$ & $\mathrm{Al}_{2} \mathrm{O}_{3}$ & 19.2 & $\cdot$ & $0.158 \times 10^{-4}$ \\
\hline & M-105-629 & $\mathrm{Al}_{2} \mathrm{O}_{3}$ & 17.1 & & 0.554 \\
\hline \multirow[t]{4}{*}{$\mathbf{B}^{\mathrm{C}}$} & $\mathrm{H}=10 \mathrm{~J}-701$ & In tube & 42,2 & 49.6 & \\
\hline & $M-105-702$ & In-tube & 42.2 & 18.8 & \\
\hline & $M-105-699$ & In-tube & 42.1 & & 0.185 \\
\hline & $M-105-700$ & In-tube & 41.4 & & 0.167 \\
\hline \multirow[t]{4}{*}{$c^{d}$} & $M-138-123$ & In-tubc & 29.7 & 5.59 & \\
\hline & $M-138-124$ & In-tube & 26.3 & 0.22 & \\
\hline & $M-138-118$ & In-tube & 28.2 & & 0.116 \\
\hline & $M-138-119$ & In-tube & 28.0 & & 0.086 \\
\hline \multirow[t]{4}{*}{$\mathrm{D}^{\mathrm{e}}$} & $M-136-70$ & In-tube & 27.0 & 0.47 & \\
\hline & $M-136-71$ & In-tube & 25.8 & 1.82 & \\
\hline & $M-136-74$ & In-tube & 26.6 & & 1.43 \\
\hline & $M-136-75$ & In-tube & 24.4 & & 0.86 \\
\hline
\end{tabular}

${ }^{a}$ Fuel rods contain only $\mathrm{ThO}_{2}$ particles and rods leached with gaseous chlorine for $2 \mathrm{hr}$ at $1500^{\circ} \mathrm{C}$.

${ }^{b}$ Grams of thorium recovered by chlorine leach per gram of thorium in rod. Desired failure fraction was $1 \times 10^{-4}$.

$c_{29}$ wt \% Asbury 6353 natural flake and 71 wt \% Ashland A-240 pitch.

$\mathrm{d}_{29}$ wt \% Asbury 6353 natural flake and 71 wt \% Ashland A-170 pitch.

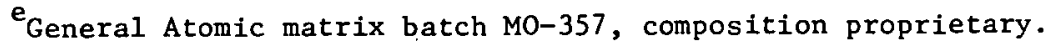




\section{DESCRIPTION OF IRRADIATION}

Both of the capsules were irradiated in the target region of the HFIR. The location of this facility is shown in Fig. 6. A detailed description of the neutron fluxes and gamma heating characteristics was previously reported ${ }^{4}$ and will not be repeated here.

${ }^{4}$ R. D. Cheverton and T. M. Sims, HFIR Core Nuclear Design, ORNL-TM-4621 (July 1971).

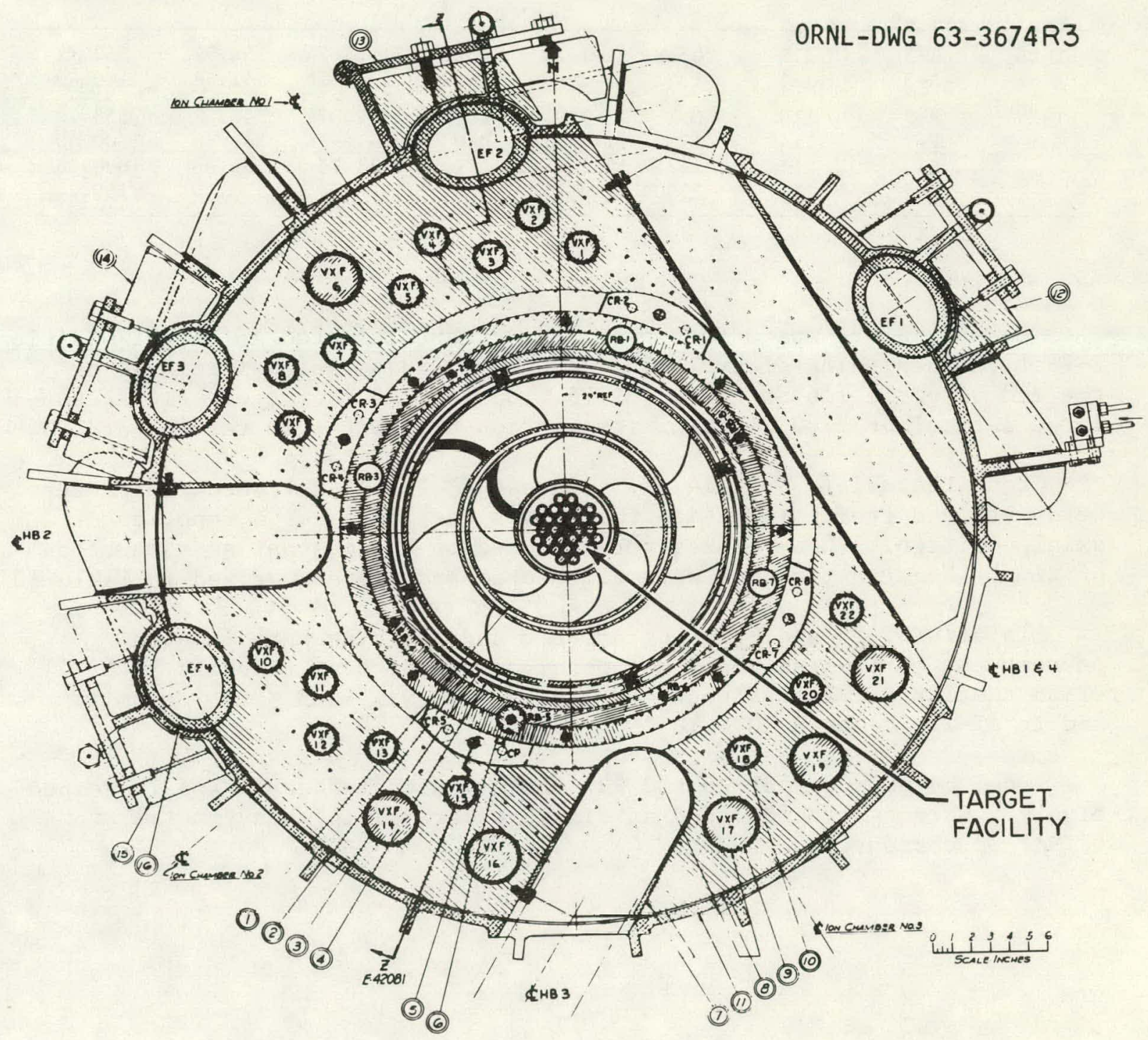

Fig. 6. Cross Section of HFIR, Showing Location of Target Facility. 
Table 9 gives an operating history of HT-26 and -27 . As can be seen from the table, HT-26 was a two-cycle experiment inserted in target position A-3 at the beginning of HFIR cycle 113 on Nov. 1, 1974, and was removed at the end of cycle 114 on Dec. 18, 1974. During the two cycles it accumulated a total of $1100.4 \mathrm{hr}$ of irradiation time with the reactor at $100 \mathrm{MW}$.

Table 9. Target Capsules HT-26 and -27 Reactor Power History

\begin{tabular}{|c|c|c|c|c|c|c|c|c|}
\hline \multirow{2}{*}{$\begin{array}{l}\text { Target } \\
\text { Capsule }\end{array}$} & \multirow{2}{*}{$\begin{array}{c}\text { Target } \\
\text { Facility }\end{array}$} & \multirow{2}{*}{$\begin{array}{c}\text { HFIR Fuel } \\
\text { Cycle }\end{array}$} & \multicolumn{2}{|c|}{ Begin } & \multicolumn{2}{|c|}{ End } & \multicolumn{2}{|c|}{ Irradiation Time, hr } \\
\hline & & & Time & Date & Time & Date & $\begin{array}{r}\text { During } \\
\text { Cycle }\end{array}$ & Accumulated \\
\hline \multirow[t]{2}{*}{$\mathrm{HT}-26$} & $A-3$ & 113 & 0818 & $11-1-74$ & 1028 & $11-24-74$ & 558.72 & 558.72 \\
\hline & $A-3$ & 114 & 1332 & $11-25-74$ & 0400 & $12-18-74$ & 541.68 & 1100.40 \\
\hline \multirow[t]{4}{*}{$\mathrm{HT}-27$} & $\mathrm{~F}-7$ & 113 & 0818 & $11-1-74$ & 1028 & $11-24-74$ & 558.72 & 558.72 \\
\hline & $\mathrm{F}-7$ & 114 & 1332 & $11-25-74$ & 0400 & $12-18-74$ & 541.68 & 1100.40 \\
\hline & $\mathrm{F}-7$ & 115 & 1435 & $12-20-74$ & 1716 & $1-11-75$ & 529.68 & 1630.08 \\
\hline & $\mathrm{F}-7$ & 116 & 1700 & $1-12-75$ & 2000 & $2-3-75$ & 530.16 & 2160.24 \\
\hline
\end{tabular}

Capsule HT-27 was a four-cycle experiment inserted in target position F-7 at the beginning of cycle 113 on Nov. 1, 1974, and was removed at the end of cycle 116 on Feb. 3, 1975. During the four cycles it accumulated a total of $2160.24 \mathrm{hr}$ of irradiation time with the reactor at $100 \mathrm{MW}$.

Both thermal $(E<0.414 \mathrm{eV})$ and fast $(E>0.18 \mathrm{MeV})$ neutron fluxes were obtained from information that gives the fluxes as a function of axial position. These fluxes were assumed to be constant as a function of time. Neutron fluences were calculated and are summarized in Table 10.

In both HT-26 and -27 , fuel rods 8 and 9 (which were located nearest the horizontal midplane) received the highest fluences. In HT-26 the largest fast fluence $(E>0.18 \mathrm{MeV})$ was $4.63 \times 10^{21} \mathrm{n} / \mathrm{cm}^{2}$, and in $\mathrm{HT}-27$ it was $9.10 \times 10^{21} \mathrm{n} / \mathrm{cm}^{2}$.

Fuel burnups for HT-26 and -27 are given in Tables 11 and 12 respectively. Burnups are reported as fissions per initial heavy-metal atom (FIMA) in percent. 
Table 10. Calculated Thermal and Fast Fluences for Target Capsules HT-26 and -27

\begin{tabular}{|c|c|c|c|c|c|c|c|}
\hline \multirow[b]{2}{*}{$\begin{array}{l}\text { Specimen } \\
\text { Number }\end{array}$} & \multirow{2}{*}{$\begin{array}{c}\text { Preirradiation } \\
\text { Distance From } \\
\text { HMP }^{\mathrm{a}} \text { to Specimen } \\
\text { (in.) }\end{array}$} & \multirow[b]{2}{*}{$\begin{array}{l}\text { Thermal Fllx, } \\
E<0.414 \mathrm{eV} \\
\left(\mathrm{n} \mathrm{cm}^{-2} \mathrm{sec}^{-1}\right)\end{array}$} & \multirow[b]{2}{*}{$\begin{array}{l}\text { Fast Flux, } \\
E>0.18 \mathrm{MeV} \\
\left(\mathrm{n} \mathrm{cm}^{-2} \mathrm{sec}^{-1}\right)\end{array}$} & \multicolumn{2}{|c|}{ HT-26 Fluence } & \multicolumn{2}{|c|}{ HT-27 Fluence } \\
\hline & & & & $\begin{array}{c}\text { Thermal, } \\
E<0.414 \mathrm{eV} \\
\left(\mathrm{n} / \mathrm{cm}^{2}\right)\end{array}$ & $\begin{array}{c}\text { Fast, } \\
E>0.18 \mathrm{MeV} \\
\left(\mathrm{n} / \mathrm{cm}^{2}\right)\end{array}$ & $\begin{array}{c}\text { Thermal, } \\
E<0.414 \mathrm{eV} \\
\left(\mathrm{n} / \mathrm{cm}^{2}\right)\end{array}$ & $\begin{aligned} & \text { Fast, } \\
& E>0.18 \mathrm{MeV} \\
&\left(\mathrm{n} / \mathrm{cm}^{2}\right)\end{aligned}$ \\
\hline 3,9 & 1.07 & $2.78 \times 10^{: 5}$ & $1.17 \times 10^{15}$ & $1.101 \times 10^{22}$ & $4.63 \times 10^{21}$ & $2.16 \times 10^{22}$ & $9.10 \times 10^{21}$ \\
\hline 7,10 & 2.00 & 2.68 & 1.15 & 1.062 & 4.56 & 2.08 & 8.94 \\
\hline 6,11 & 2.94 & 2.56 & 1.11 & 1.014 & 4.39 & 1.99 & 8.63 \\
\hline 5,12 & 3.88 & 2.42 & 1.07 & 0.959 & 4.24 & 1.88 & 8.32 \\
\hline 4,13 & 6.07 & 2.06 & 0.91 & 0.816 & 3.61 & 1.60 & 7.08 \\
\hline 3,14 & 7.00 & 1.89 & 0.815 & 0.749 & 3.23 & 1.47 & 6.34 \\
\hline 2,15 & 7.94 & 1.70 & 0.710 & 0.673 & 2.81 & 1.32 & 5.52 \\
\hline 1,16 & 8.88 & 1.52 & 0.602 & 0.602 & 2.38 & 1.18 & 4.68 \\
\hline
\end{tabular}

aHorizontal midplane. 
Table 11. Fuel Particle Burnup for HT-26

\begin{tabular}{ccccc}
\hline \multirow{2}{*}{$\begin{array}{c}\text { Specimen } \\
\text { Number }\end{array}$} & $\begin{array}{c}\text { Distance From } \\
\text { Horizontal Midplane } \\
\text { (in.) }\end{array}$ & \multicolumn{3}{c}{ Burnup, \% FIMA } \\
\cline { 3 - 5 } & 8.88 & 81.71 & 5.10 & $2{ }^{23} \mathrm{U}$ \\
\hline 1,16 & 7.94 & 82.55 & 5.92 & 1.35 \\
2,15 & 7.00 & 83.26 & 6.65 & 1.62 \\
3,14 & 6.07 & 83.83 & 7.25 & 2.88 \\
4,13 & 3.88 & 84.50 & 8.25 & 2.52 \\
5,12 & 2.94 & 84.65 & 8.55 & 2.65 \\
6,11 & 2.00 & 84.70 & 8.70 & 2.72 \\
7,10 & 1.07 & 84.75 & 8.89 & 2.80 \\
8,9 & & & & \\
\hline
\end{tabular}

Table 12. Fuel Particle Burnup for HT-27

\begin{tabular}{ccccc}
\hline \multirow{2}{*}{$\begin{array}{c}\text { Specimen } \\
\text { Number }\end{array}$} & $\begin{array}{c}\text { Distance From } \\
\text { Horizonta1 Midplane } \\
\text { (in.) }\end{array}$ & \multicolumn{3}{c}{ Burnup, \% FIMA } \\
\cline { 3 - 5 } & 8.88 & 84.25 & 11.40 & 5.02 \\
1,16 & 7.94 & 84.35 & 13.05 & 5.80 \\
2,15 & 7.00 & 84.45 & 14.37 & 6.60 \\
3,14 & 6.07 & 84.55 & 15.49 & 7.20 \\
4,13 & 3.88 & 84.75 & 17.25 & 8.40 \\
5,12 & 2.94 & 84.80 & 17.80 & 8.70 \\
6,11 & 2.00 & 84.85 & 18.20 & 8.90 \\
7,10 & 1.07 & 84.86 & 18.50 & 9.05 \\
8,9 & & & & \\
\hline
\end{tabular}


When HT-26 was disassembled, all fuel rods in the high-temperature and -fluence regions of the capsule (i.e., rods 5 through 12 ) were badly debonded, while those in the low-temperature and-fluence regions (i.e., rods 1 through 4 and 13 through 16) were in excellent condition. Representative photomacrographs of the rods after irradiation are shown in Fig. 7. A summary of the visual examination is given in Table 13 .

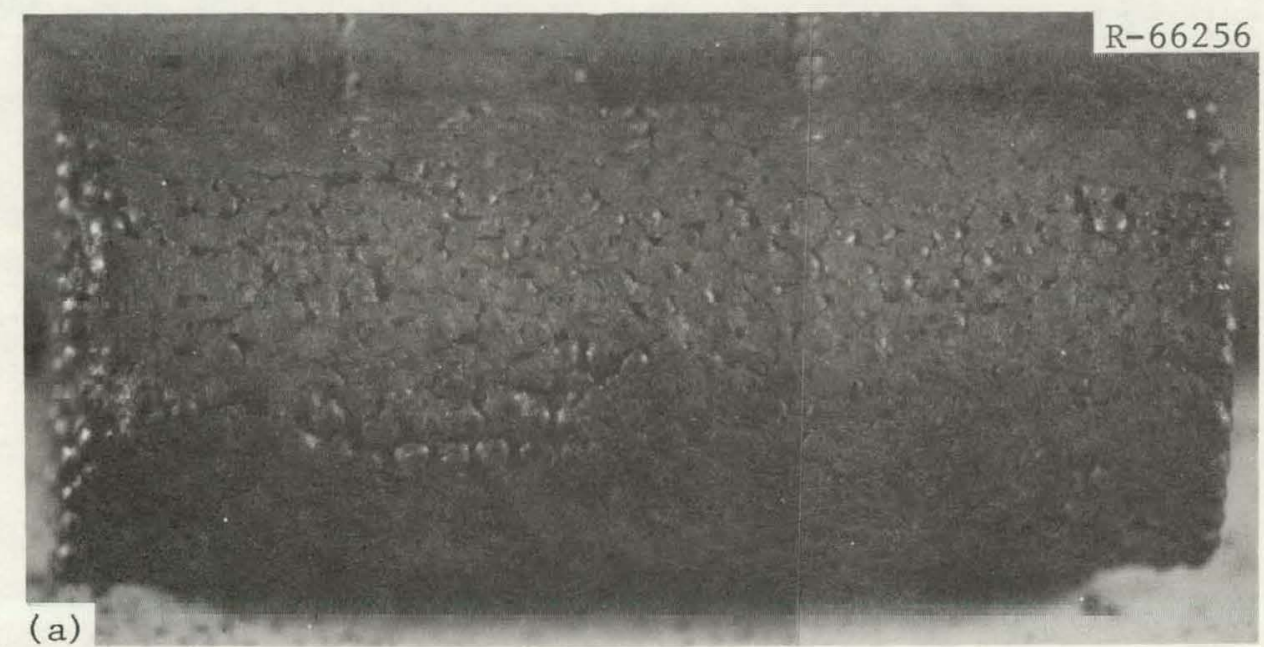

$$
\leftarrow / 2 \text { in. } \rightarrow
$$

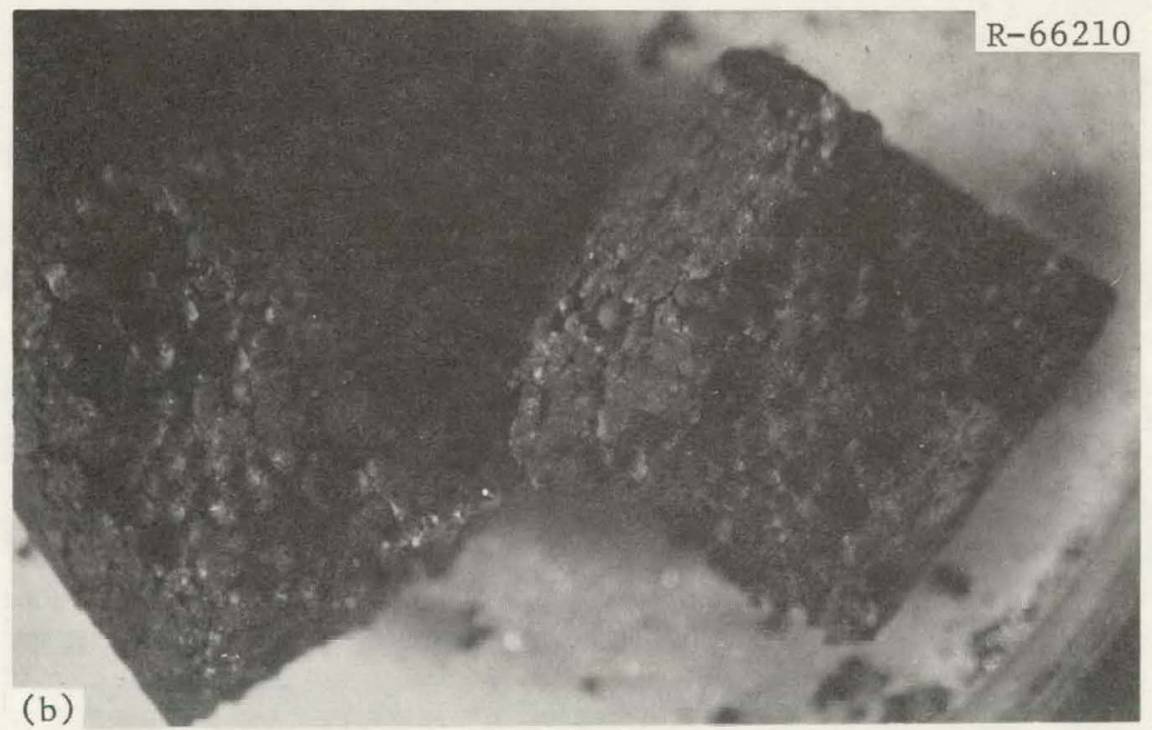

Fig. 7. Representative Photomacrographs of Fuel Rods After Irradiation from: (a) The Low-Temperature Region (Rod 13), and (b) The High-Temperature Region (Rod 7) in HT-26. Note the debonding in the high-temperature rod, while the low-temperature rod was intact. 
Table 13. Summa $=y$ of Visua1 Examination of HT-26

\begin{tabular}{|c|c|c|c|c|c|c|}
\hline $\begin{array}{c}\text { Rod } \\
\text { Position } \\
\text { in } \\
\text { Capsule }\end{array}$ & $\begin{array}{l}\text { Approximate } \\
\text { Surface } \\
\text { Temperature } \\
\left({ }^{\circ} \mathrm{C}\right)\end{array}$ & $\begin{array}{c}\text { Matrix } \\
\text { Typea }\end{array}$ & $\begin{array}{l}\text { Carbonizatior. } \\
\text { Mode }\end{array}$ & $\begin{array}{l}\text { Coke } \\
\text { Yield } \\
\text { (wt \%) }\end{array}$ & $\begin{array}{l}\text { General Condition } \\
\text { of Rod }\end{array}$ & Stereoscopic Examination \\
\hline 1 & 900 & B & In-tube & 40.8 & Good, no debonding & No failed particles on surface \\
\hline 2 & 900 & B & In-tube & 42.0 & Good, no debonding & No failed particles on surface \\
\hline 3 & 900 & A & In $\mathrm{Al}_{2} \mathrm{O}_{3}$ & 19.4 & Good, no debonding & No failed particles on surface \\
\hline 4 & 900 & $\mathrm{D}$ & In-tube & 26.4 & Good, no debonding & No failed particles on surface \\
\hline 5 & 1250 & C & In-tube & 28.0 & $\begin{array}{l}\text { Very extensive debonding } \\
\text { ( } 2 \text { large sections } \\
\text { remain) }\end{array}$ & $\begin{array}{l}\text { A number of failed particles observed } \\
\text { with outer coacings removed }\end{array}$ \\
\hline 6 & 1250 & B & In-tube & 41.0 & Complete debonding & No failed particles observed \\
\hline 7 & 1250 & D & In-tube & 24.1 & $\begin{array}{l}\text { Extensive debonding } \\
\text { ( } 2 \text { large sections } \\
\text { remain) }\end{array}$ & $\begin{array}{l}\text { One failed particle observed (type } \\
\text { unknown) }\end{array}$ \\
\hline 8 & 1250 & B & In-tube & 42.5 & Complete debonding & No failed particles observed \\
\hline 9 & 1250 & B & In-tube & 39.7 & Very extensive debonding & $\begin{array}{l}\text { A number of failed particles observed } \\
\text { (types unknown) }\end{array}$ \\
\hline 10 & 1250 & D & In-tube & 27.1 & Intact, but very fragile & No observation made \\
\hline 11 & 1250 & C & In-tube & 28.4 & Intact, but very fragile & No observation made \\
\hline 12 & 1250 & B & In-tube & 41.5 & Complete debonding & $\begin{array}{l}\text { A number of failed particles observed } \\
\text { (types unknown) }\end{array}$ \\
\hline 13 & 900 & $\mathrm{D}$ & In-tube & 24.9 & Good, no debonding & No failed particles on surface \\
\hline 14 & 900 & A & In $\mathrm{Al}_{2} \mathrm{O}_{3}$ & 20.2 & Good, no debonding & No failed particles on surface \\
\hline 15 & 900 & B & In-tube & 41.5 & Good, no debonding & No failed particles on surface \\
\hline 16 & 900 & B & In-tube & 41.7 & Good, no debonding & No failed particles on surface \\
\hline
\end{tabular}

a Matrix types are as follows: Type A contains high-coke-yield Ashland A-240 pitch carbonized in $\mathrm{Al}_{2} \mathrm{O}_{3}$. Type $\mathrm{B}_{\text {contains }}$ Ashland A-240 pitch carbonized in a graphite tube. Type C contains low-coke-yield A-170 pitch carbonized in a graphite tube. Type D is current GAC matrix carbonized in a graphite tube. 
Additional visual examination revealed a large number of small holes ( $<0.05 \mathrm{~cm}$ in diameter) associated with the graphite magazines from the high-temperature region. The holes are shown in Fig. 8, which is a photomacrograph of a magazine outer surface. Examination of the inner surface of the magazines (from the high-temperature region) showed that the holes extended through the graphite. No direct path could be seen; that is, the holes did not appear to be straight.

The holes were isolated metallographically, and microprobe analysis revealed concentrations of iron and vanadium surrounding the holes. These results are shown in Fig. 9. The holes evidently followed agglomerates (areas of high density formed by fines and a high proportion of pitch), where the iron and vanadium appear as impurities from the pitch.

This type of phenomenon has been observed before and is due to attack of the graphite by steam. As a result, the indications are that the HT-26 capsule developed a leak during or prior to irradiation. This would explain the appearance of holes in the graphite magazines and debonding of the fuel rods due to formation and attack of steam. In light of these results, further examination of the HT-26 capsule was stopped. (The visual and dimensional examinations had been completed and chlorine leaching of rods 1,2 , and 3 finished. Chlorine leaching of rods 5 through 12 was not scheduled because of the debonding.)

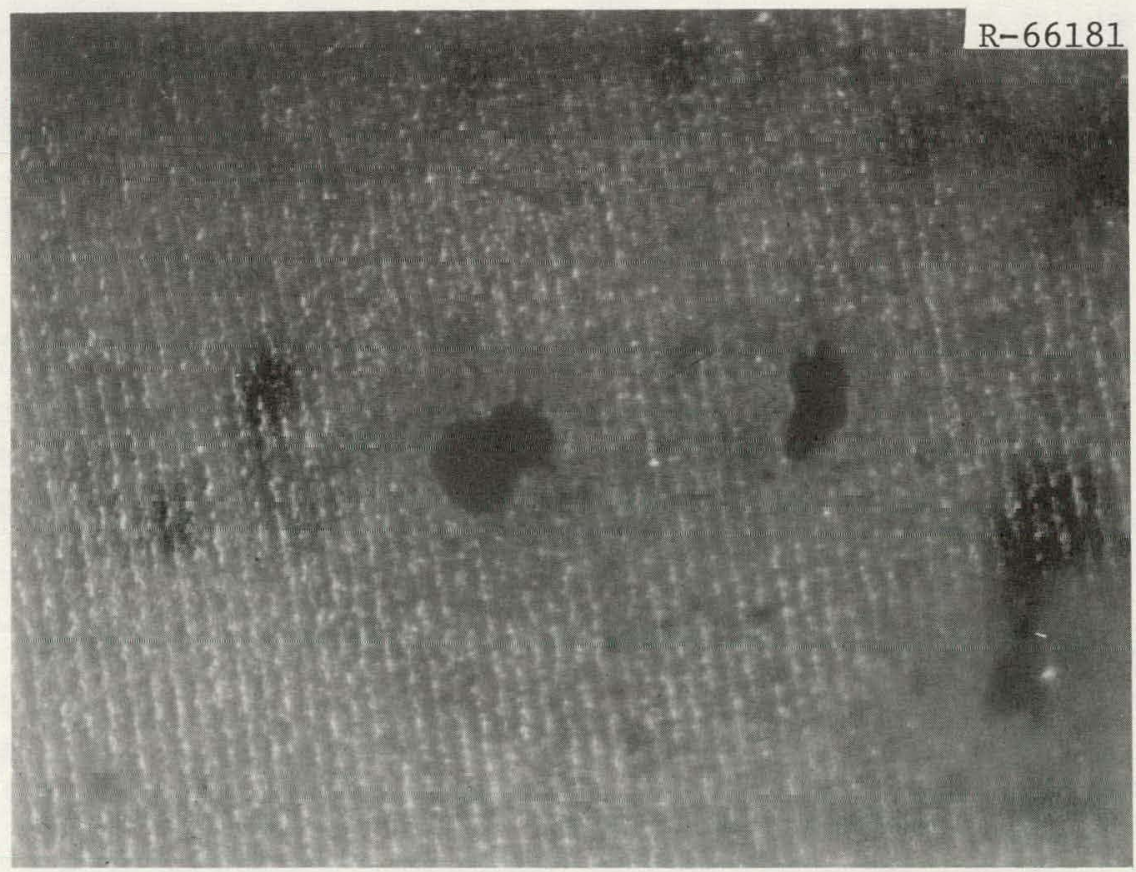

Fig. 8. Photomacrograph of Holes Present on Outer Surface of Graphite Magazine in High-Temperature Region of HT-26. 27×. 

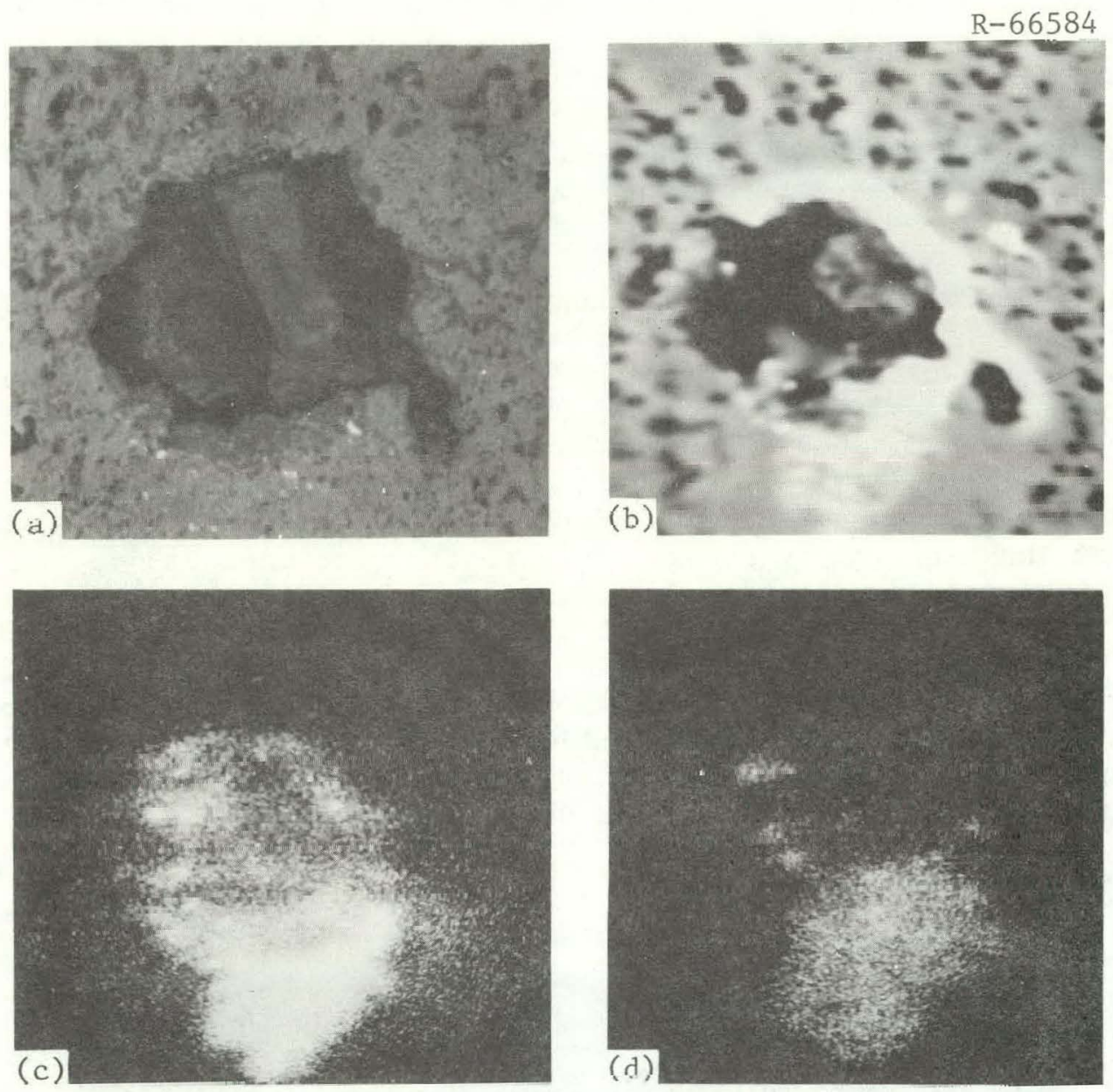

Fig. 9. Microprobe Results Showing Concentrations of Iron and Vanadium Surrounding the Holes From High-Temperature Graphite Magazines in HT-26. 500×. (a) Optical, (b) specimen current, (c) $F e L_{\alpha}$, (d) $V \mathrm{~L}_{\alpha}$.

It should be pointed out that as a consequence of the possible leakage, gas samples from HT capsules are now taken which prove definitely whether they had a leak during operation $\left(\mathrm{H}_{2} \mathrm{O}\right.$ would be detected if a leak was present). Gas sampling also aids in postirradiation thermal analyses.

When the HT-27 capsule was disassembled, no problems were encountered, and all fuel rods were removed intact and in excellent condition. Visual examination of the fuel rods revealed no failed particles on the outer surfaces and no debonding of the rods. However, the zirconium foils, used as oxygen getters and placed between the fuel rods, had adhered to the ends of the rods from the high-temperature region (i.e., rods 5 through 12). The zirconium foils had been separated from the fuel rods by Grafoil wafers; but apparently a reaction had occurred that extended through the Grafoil into the fuel rods. Representative rods are shown in Figs. 10 and 11. No evidence of the zirconium adhering to the rods from the low-tempeature regions was observed. 

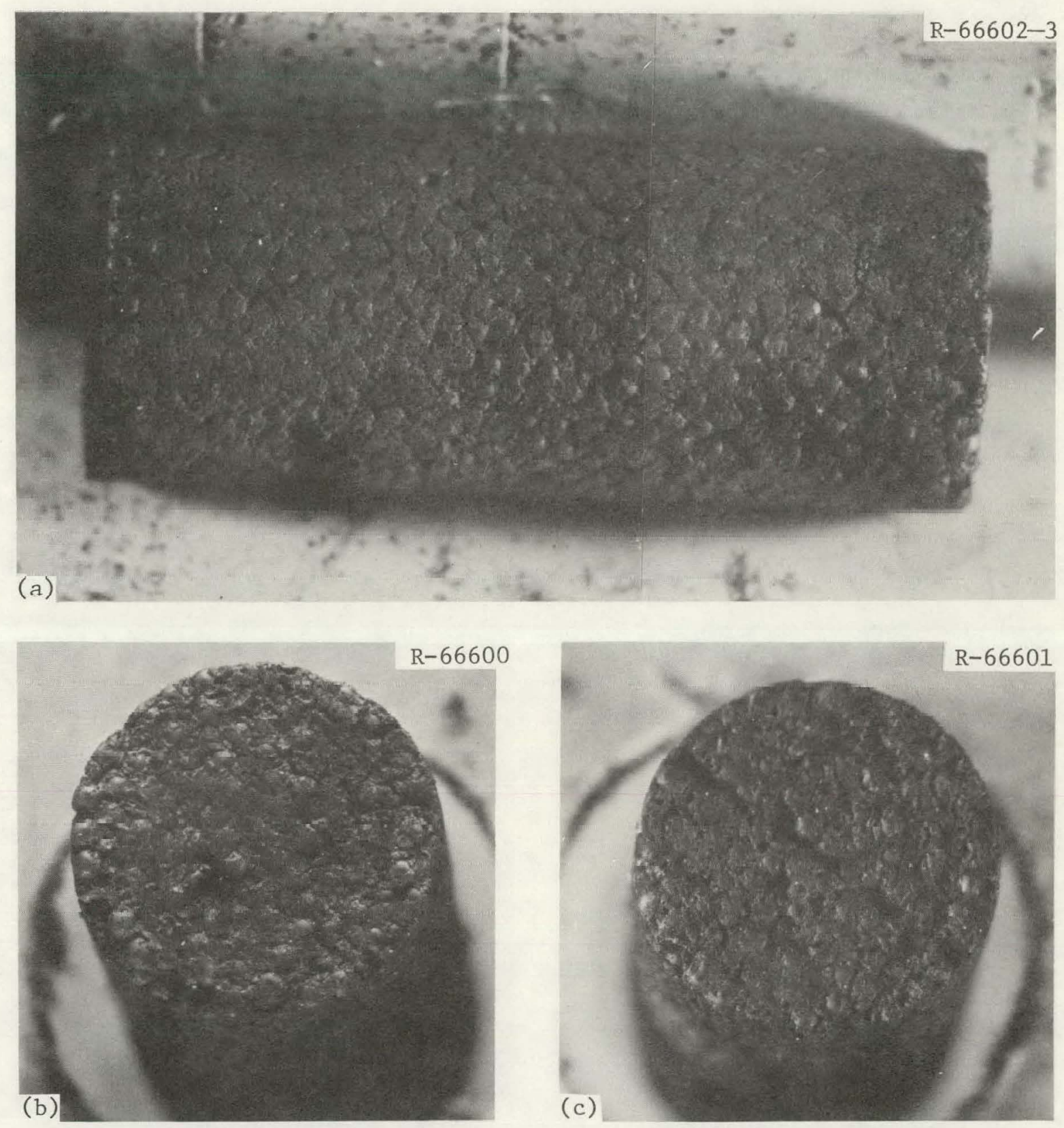

Fig. 10. Representative Fuel Rod (No. 3) From Low-Temperature Region $\Lambda$ fer Irradiation in HT-27. (a) Side view, (b) top view, (c) bottom view. $6 \times$. 

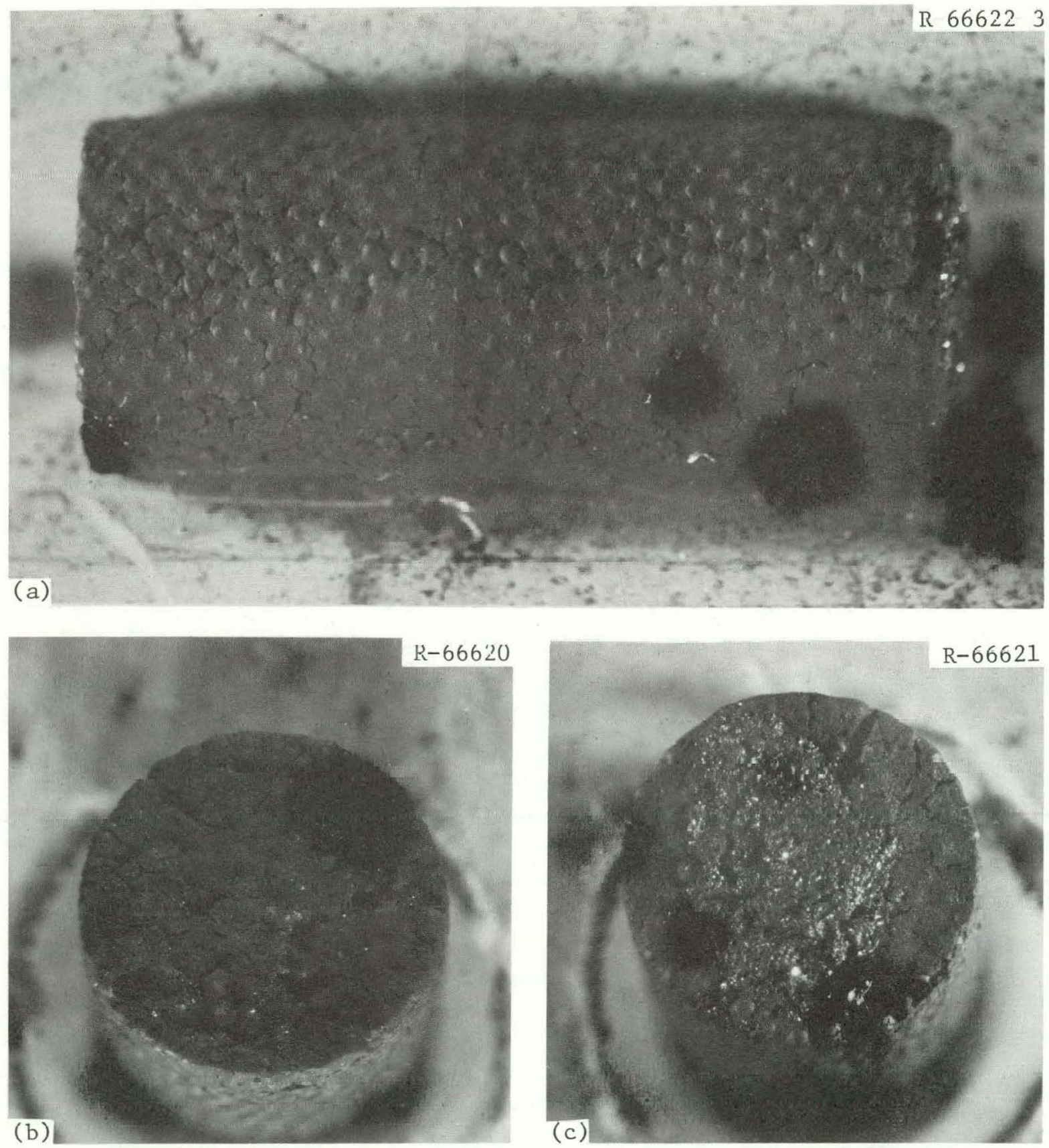

Fig. 11. Representative Fuel Rod (No. 8) From High-Temperature Region After Irradiation in HT-27. (a) Side view, (b) top view, (c) bottom view. Note appearance of large amounts of zirconium on bottom of rod and very little on the top. $6 \times$. 
Dimensional analyses on HT-26 and -27 were made, but both were incomplete. In HT-26 the rods from the high-temperature region (rods 5 to 12) had no measurements taken because of the debonding encountered. In HT-27 the lengths of the rods in the high-temperature region (rods 5 to 12) could not be taken because of the zirconium adhering to the ends. Diameters of the fuel rods were measured at the top, midlength, and bottom at 0 and $90^{\circ}$. Tables 14 and 15 give summaries of the dimensional changes for HT-26 and -27 respectively. The fuel rods experienced shrinkages, with the greater changes at the higher temperatures and fluences. In every case the lengths of the rods shrank more than the diameters. This anistropic shrinkage is in part a characteristic of the slug-injection method, where the graphite filler particles are preferentially oriented, leading to differential shrinkage.

$\Lambda$ thermal analysis was performed using the postirradiation examination (PIE) dimensions, which took into account the radial shrinkages of the fuel rods. The preirradiation thermal analysis did not incorporate changes in fuel rod dimensions. A detailed description of the thermal analyses is given in the appendix. It was calculated that the operating fuel surface temperatures increased from 89 to $121^{\circ} \mathrm{C}$ above the design surface temperatures of 900 and $1250^{\circ} \mathrm{C}$. It was also calculated that the fuel centerline temperatures were 89 to $151^{\circ} \mathrm{C}$ above the anticipated temperatures.

Chlorine leach tests to determine particle failure fractions were performed on rods 1,2 , and 3 from HT-26 and on all rods from HT- 27 . The tests are carried out by heating a rod to $1000^{\circ} \mathrm{C}$ and passing hot chlorine gas over it. Volatile heavy-metal chlorides are formed which can be collected (by condensation) and measured. A chlorination cycle of approximately $20 \mathrm{hr}$ was used after a time study was done to determine evolution rate. In addition to the spectrophotometric measurement of thorium and the fluorometric measurement of uranium, the volatiles collected were examined by gamma spectrometry and spark source mass spectrometry to determine the presence of fission and activation products and impurities. The results are given in Table 16. As shown, high failure fractiuns were found in the rods trom the high-fluence and -temperature regions.

In addition to the uranium, thorium, fission products, and ${ }^{233} \mathrm{~Pa}$ that are expected to be recovered from failed irradiated particles, iron activation products ${ }^{59} \mathrm{Fe},{ }^{51} \mathrm{Cr}$, and ${ }^{54} \mathrm{Mn}$ were also observed. The fission products and activation products included: ${ }^{95} \mathrm{Zr},{ }^{95} \mathrm{Nb},{ }^{103} \mathrm{Ru}$,

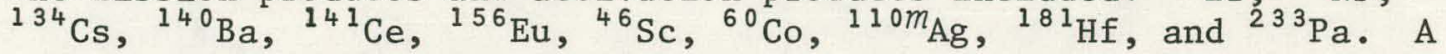
subsequent investigation found that the iron contamination was from the graphite magazines (made of Poco AXF-5Q), from where it had evidently migrated into the rods during irradiation. 
Table 14. Summary of Dimensional Changes for HT-26

\begin{tabular}{|c|c|c|c|c|c|c|c|}
\hline \multirow{2}{*}{$\begin{array}{l}\text { Rod } \\
\text { Number }\end{array}$} & \multirow{2}{*}{$\begin{array}{c}\text { Approximate } \\
\text { Surface } \\
\text { Temperature } \\
\left({ }^{\circ} \mathrm{C}\right)\end{array}$} & \multicolumn{5}{|c|}{$\begin{array}{l}\text { Postirradiation Dimensional Change } \\
\text { and Diameter-to-Length Change Ratio }\end{array}$} & \multirow{2}{*}{$\begin{array}{l}\text { Fast Fluence, } \\
E>0.18 \mathrm{MeV} \\
\left(\mathrm{n} / \mathrm{cm}^{2}\right)\end{array}$} \\
\hline & & $\begin{array}{l}\Delta D \\
\text { (in.) }\end{array}$ & $\begin{array}{c}\% \\
\text { Change }\end{array}$ & $\stackrel{\Delta L}{(\text { in. })}$ & $\begin{array}{c}\% \\
\text { Change }\end{array}$ & $\frac{\Delta D}{D} / \frac{\Delta L}{L}$ & \\
\hline 1 & 900 & 0.0106 & -2.80 & 0.0341 & -3.67 & 0.76 & $2.2 \times 10^{21}$ \\
\hline 2 & 900 & 0.0132 & -3.48 & 0.0337 & -3.63 & 0.96 & 2.8 \\
\hline 3 & 900 & 0.0129 & -3.36 & 0.0315 & -3.41 & 0.99 & 3.2 \\
\hline 4 & 900 & 0.0131 & -3.41 & 0.0353 & -3.87 & 0.88 & 3.6 \\
\hline 13 & 900 & 0.0133 & -3.48 & 0.0072 & -4.60 & 0.76 & 3.6 \\
\hline 14 & 900 & 0.0116 & -3.04 & 0.0311 & -3.37 & 0.90 & 3.2 \\
\hline 15 & 900 & 0.0123 & -3.24 & 0.0327 & -3.54 & 0.92 & 2.8 \\
\hline 16 & 900 & 0.0121 & -3.19 & 0.0393 & -4.26 & 0.75 & 2.2 \\
\hline
\end{tabular}

Table 15. Summary of Dimensional Changes for HT-27

\begin{tabular}{|c|c|c|c|c|c|c|c|}
\hline \multirow{2}{*}{$\begin{array}{l}\text { Rod } \\
\text { Number }\end{array}$} & \multirow{2}{*}{$\begin{array}{c}\text { Approximate } \\
\text { Surface } \\
\text { Temperature } \\
\left({ }^{\circ} \mathrm{C}\right)\end{array}$} & \multicolumn{5}{|c|}{$\begin{array}{l}\text { Postirradiation Dimensional Change } \\
\text { and Diameter-to-Length Change Ratio }\end{array}$} & \multirow{2}{*}{$\begin{array}{l}\text { Fast Fluence, } \\
E>0.18 \mathrm{MeV} \\
\quad\left(\mathrm{n} / \mathrm{cm}^{2}\right)\end{array}$} \\
\hline & & $\begin{array}{l}\Delta D \\
\text { (in.) }\end{array}$ & $\begin{array}{c}\% \\
\text { Change }\end{array}$ & $\begin{array}{l}\Delta L \\
\text { (in.) }\end{array}$ & $\begin{array}{c}\% \\
\text { Change }\end{array}$ & $\frac{\Delta D}{D} / \frac{\Delta L}{L}$ & \\
\hline 1 & 900 & 0.0129 & -3.40 & 0.0387 & -4.17 & 0.82 & $4.6 \times 10^{21}$ \\
\hline 2 & 900 & 0.0105 & -2.76 & 0.0410 & -4.44 & 0.62 & 5.6 \\
\hline 3 & 900 & 0.0144 & -3.77 & 0.0428 & -4.62 & 0.82 & 6.4 \\
\hline 4 & 900 & 0.0136 & -3.55 & 0.0435 & -4.72 & 0.75 & 7.1 \\
\hline 5 & 1250 & 0.0141 & -3.69 & 0.0364 & -3.97 & 0.93 & 8.1 \\
\hline 6 & 1250 & 0.0144 & -3.78 & 0.0456 & -4.89 & 0.77 & 8.4 \\
\hline 7 & 1250 & 0.0142 & -3.73 & & & & 8.8 \\
\hline 8 & 1250 & 0.0172 & -4.49 & & & & 9.0 \\
\hline 9 & 1250 & 0.0157 & -4.10 & & & & 9.0 \\
\hline 10 & 1250 & 0.0139 & -3.66 & & & & 8.8 \\
\hline 11 & 1250 & 0.0145 & -3.78 & & & & 8.4 \\
\hline 12 & 1250 & 0.0137 & -3.62 & & & & 8.1 \\
\hline 13 & 900 & 0.0139 & -3.63 & 0.0417 & -4.48 & 0.81 & 7.1 \\
\hline 14 & 900 & 0.0138 & -3.61 & 0.0427 & -4.57 & 0.79 & 6.4 \\
\hline 15 & 900 & 0.0129 & -3.24 & 0.0476 & -5.09 & 0.64 & 5.6 \\
\hline 16 & 900 & 0.0126 & -3.32 & 0.0419 & -4.55 & 0.73 & 4.6 \\
\hline
\end{tabular}


Table 16. Summary of Results from Chlorine Leach Tests

\begin{tabular}{|c|c|c|c|c|c|c|c|c|}
\hline \multirow{2}{*}{$\begin{array}{c}\text { Rod } \\
\text { Number }\end{array}$} & \multirow{2}{*}{$\begin{array}{c}\text { Approximate } \\
\text { Fuel Surface } \\
\text { Temperature } \\
\left({ }^{\circ} \mathrm{C}\right)\end{array}$} & \multirow{2}{*}{$\begin{array}{c}\text { Average } \\
\text { Fast Fluence, } \\
E>0.18 \mathrm{MeV} \\
\left(\mathrm{r} / \mathrm{cm}^{2}\right)\end{array}$} & \multirow{2}{*}{$\begin{array}{c}\text { Pitch-Coke } \\
\text { Yield } \\
(\%)\end{array}$} & \multicolumn{3}{|c|}{ Total Metal Recovered, $\mu \mathrm{g}$} & \multicolumn{2}{|c|}{ Percent Failed ${ }^{a}$} \\
\hline & & & & $\mathrm{U}$ & Th & $\mathrm{Fe}$ & $\mathrm{U}$ & Th \\
\hline HT-26-1 & 900 & $2.3 \varepsilon \times 10^{21}$ & $40.8^{\mathrm{b}}$ & 20 & $<10$ & 200 & & \\
\hline-2 & 900 & 2.81 & $42.0^{\mathrm{b}}$ & 100 & 1,380 & d & & \\
\hline-3 & 900 & 3.23 & $19.4^{\mathrm{C}}$ & 30 & $<10$ & $\mathrm{~d}$ & & \\
\hline HT-27-1 & 900 & 4.68 & $40.7^{b}$ & 27 & 38 & $d$ & 0.15 & 0.08 \\
\hline-2 & 900 & 5.52 & $43.1^{\mathrm{b}}$ & 10 & 28 & $d$ & 0.05 & 0.06 \\
\hline-3 & 900 & 6.34 & $28.9^{\mathrm{b}}$ & 95 & 20 & $\mathrm{~d}$ & 0.54 & 0.05 \\
\hline-4 & 900 & 7.08 & $27.0^{\mathrm{b}}$ & $<10$ & 24 & $\mathrm{~d}$ & 0.06 & 0.06 \\
\hline-5 & 1250 & 8.32 & $24.6^{b}$ & 2000 & 1,870 & d & 8.26 & 3.05 \\
\hline-6 & 1250 & 8.63 & $38.4^{b}$ & 4100 & 6,440 & $\mathrm{~d}$ & 17.04 & 10.54 \\
\hline-7 & 1250 & 8.94 & $39.9^{b}$ & 5540 & 10,700 & 10,000 & 23.14 & 17.56 \\
\hline-8 & 1250 & 9.10 & $18.8^{c}$ & 3350 & 7,290 & d & 14.05 & 11.98 \\
\hline-9 & 1250 & 9.10 & $18.7^{\mathrm{C}}$ & 3420 & 8,430 & 21,000 & 14.34 & 13.86 \\
\hline-10 & 1250 & 8.94 & $41.5^{b}$ & 6100 & 8,390 & d & 25.48 & 13.77 \\
\hline-11 & 1250 & 8.63 & $25.1^{\mathrm{b}}$ & 1620 & 2,660 & 20,000 & 6.73 & 4.36 \\
\hline-12 & 1250 & 8.32 & $39.4^{b}$ & 4900 & 12,500 & d & 20.23 & 20.40 \\
\hline-13 & 900 & 7.08 & $26.2^{\mathrm{b}}$ & 60 & $<10$ & 300 & 0.34 & 0.02 \\
\hline-14 & 900 & 6.34 & $27.4^{b}$ & 29 & 50 & d & 0.16 & 0.11 \\
\hline-15 & 900 & 5.52 & $41.0^{\mathrm{b}}$ & $<10$ & $<25$ & 300 & 0.06 & 0.06 \\
\hline-16 & 900 & 4.68 & $39.7^{b}$ & 23 & 38 & $\mathrm{~d}$ & 0.13 & 0.08 \\
\hline
\end{tabular}

a Burnup corrections made.

${ }^{b}$ Carbonized in graphite tube.

${ }^{C}$ Carbonized in packed $\mathrm{Al}_{2} \mathrm{O}_{3}$ powder.

$\mathrm{d}_{\text {Not determined. }}$ 
After the chlorine leach, metallography was performed on selected fuel rods from the high-temperature region of HT-27. Results, as shown in Figs. 12 and 13, indicate an extensive reaction of the zirconium foil with the carbon in the fuel rods and destruction of many particles. Because the reaction took place mainly at the rod centerlines (extending into the rod as shown in Fig. 13) and did not necessarily attack both ends, it is believed to be governed by how much contact the rods had with the zirconium (i.e., the closer the contact, the greater the reaction) and by the temperature. It was also observed that the fueled particles had been attacked to a greater extent than had the inert particles (probably because they were generating heat).

The zirconium reaction with the fuel rods causes the chlorine leach results to be at best compromised, because an attacked fuel particle would show up as a failed particle. Thus the chlorine leach results from the fuel rods in the high-temperature region of HT-27 cannot be interpreted, since the zirconium reaction caused many fueled particles to fail. The failure fractions depended on the extent of the reaction and the number of fueled particles in close proximity to the zirconium, not matrix-particle interaction, as had been expected.

Since no zirconium reaction was observed to be associated with the low-temperature fuel rods, those results are believed to be accurate. In each case, very low failure fractions were recorded.

Metallography also revealed a problem associated with the chlorine leach analysis. In addition to leaching of exposed thorium and uranium, the chlorine gas attacks $\mathrm{SiC}$ by the following equation: ${ }^{5}$

$$
\mathrm{SiC}+2 \mathrm{C}_{2} \longrightarrow \mathrm{SiCl}_{4} \uparrow+\mathrm{C}
$$

The $\mathrm{SiCl}_{4}$ is very volatile. The particle shown in Fig. 14 had the outer LTI cracked, and attack of the SiC coating is evident. The color of the SiC coating has darkened, and it is believed that the coating no longer contains any silicon. Subsequent tests on unirradiated particles have shown that the coating loses all of the silicon and is essentially carbon. ${ }^{6}$ It should be noted that although the particle in Fig. 14 no longer has an SiC coating, none of the kernel appears to have been leached.

\footnotetext{
${ }^{5}$ J. Nickl and K. Braunnühl, Z. Anal. Chem. 221: 223-28 (1966).

${ }^{6}$ Personal communication with D. Costanzo.
} 


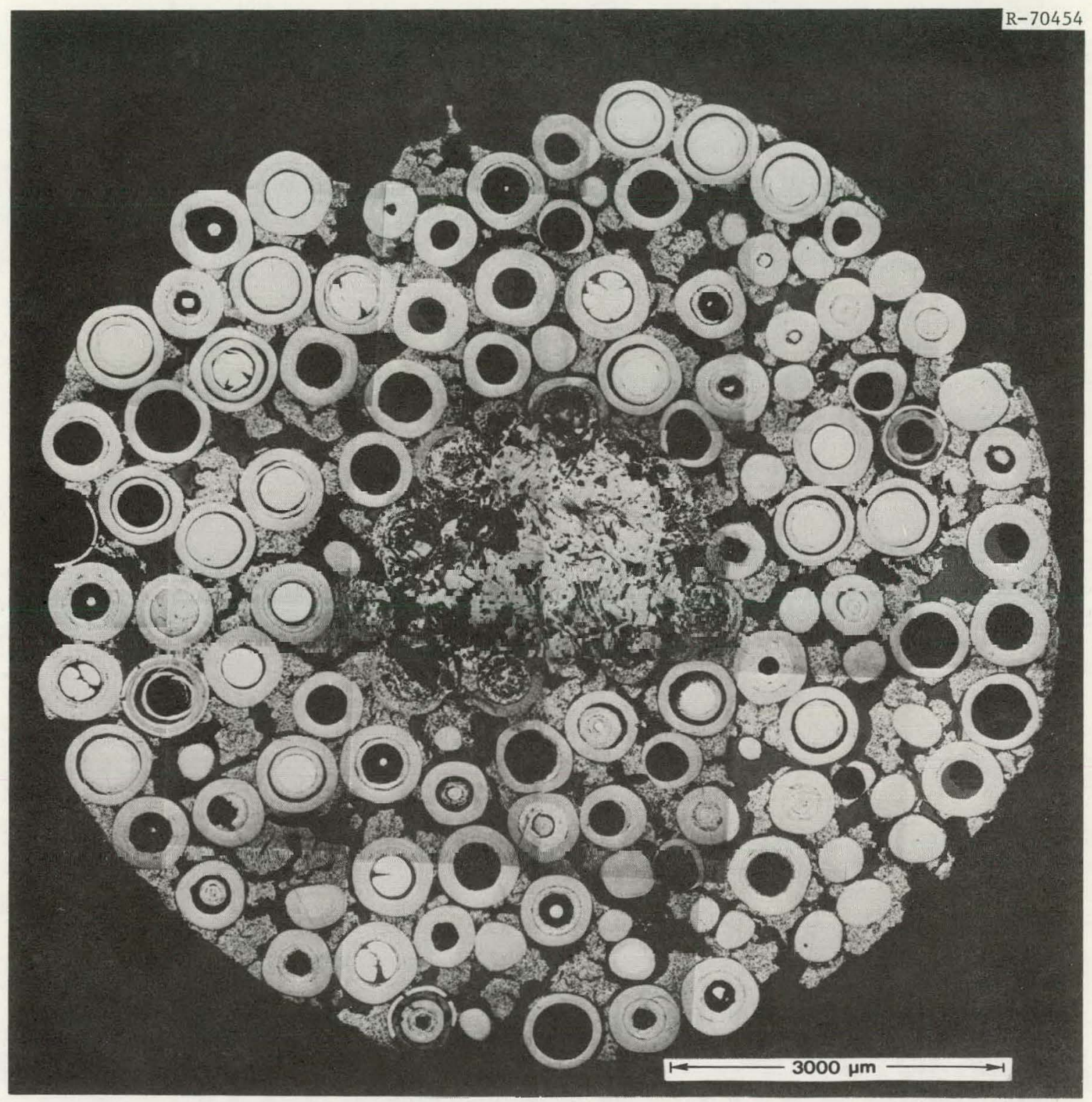

Fig. 12. Transverse Section Through Fuel Rod 10 From the HighTemperature Region of HT-27, Showing Result of Reaction With Zirconium Getter. 


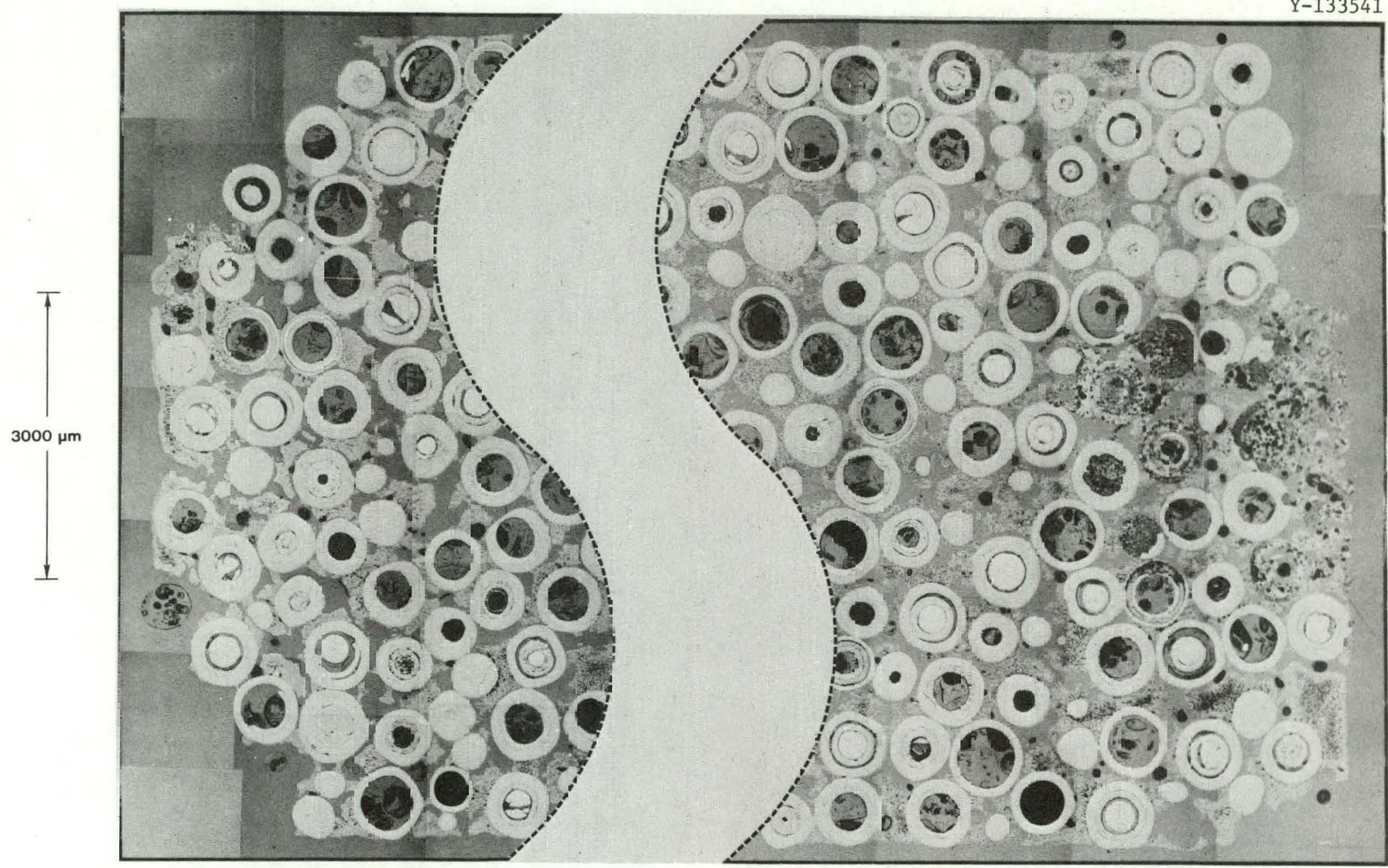

Fig. 13. Lcngitudinal Section Through Fuel Rod 8 From High-Temperature Region of HT-27, Showing Result of Reaction with Zircorim Getter. Note tot om of rod is on the right. 


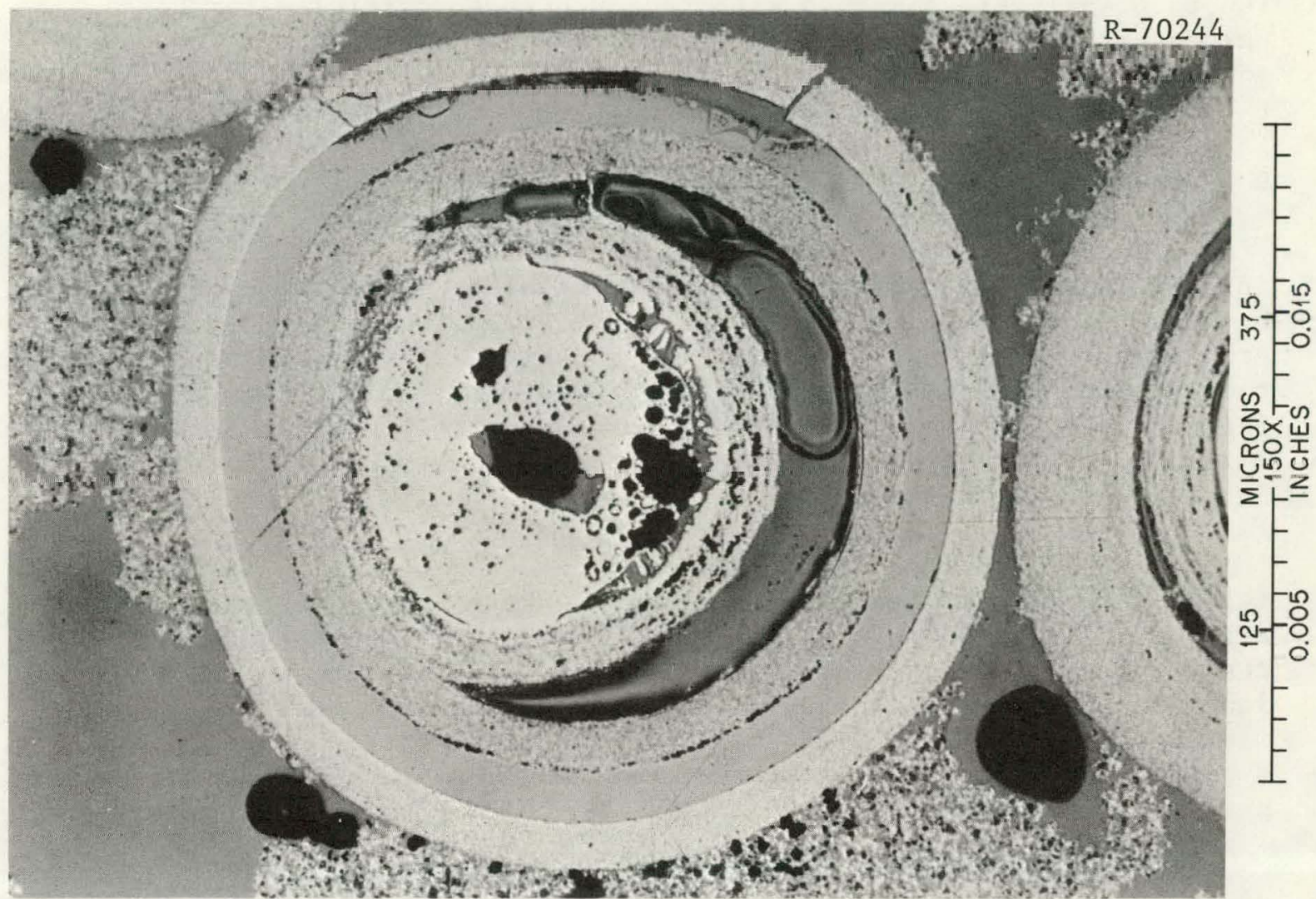

Fig. 14. Example of SiC Coating Attack by Gaseous Chlorine. Note that the SiC has darkened.

\section{DISCUSSION AND CONCLUSIONS}

The first objective of the HT-26 and -27 tests was to fabricate fuel with a failed fuel fraction less than $0.1 \%\left(1 \times 10^{-3}\right)$. This objective was accomplished for both Trisu-cualed fissile particles and Biso-coated fertile particles. With the Triso-coated particles, the failed fuel specification was met by both unannealed and not surface treated, and annealed and surface treated particles. This may be due in part to the stability of the SiC coating, but it is not definite at this time. ${ }^{7}$ In any event, it was demonstrated that fuel rods could be fabricated with a failure fraction of Triso-coated particles $<0.1 \%$. On the other hand, the Biso-coated particles showed a significant difference between those annealed and unannealed. As shown in Table 8, high failure fractions

${ }^{7}$ W. J. Lackey, D. P. Stinton, L. E. Davis, and R. L. Beatty, Crushing Strength of HTGR Fuel Particles, ORNL/TM-5132 (January 1976). 
(up to $0.49 \%$ ) were observed with the unannealed particles for both carbonization modes (packed $\mathrm{Al}_{2} \mathrm{O}_{3}$ and in-tube) and high and low pitchcoke yields. The annealed particles showed very low failed fuel fractions $(\leqslant 0.0143 \%)$ regardless of the carbonization mode or pitch-coke yield. This indicates the desirability to anneal Biso-coated particles prior to irradiation.

Objective 2, which was to determine the effect of matrix-particle interaction on the particle failure fraction of irradiated fuel ( $<1 \%$ for acceptable results), was not completely accomplished due to unexpected problems. In the case of HT-26, the capsule had evidently leaked, and the graphite components were attacked by steam. This attack led to fuel rod debonding and is believed to have caused particle failure. As a result, no significant information could be obtained on matrix-particle interaction from HT-26.

In HT-27, half of the fuel rods (those from the high-temperature region) experienced attack by zirconium. Metallography showed that the zirconium caused failure of many fuel particles and consequently exposed the kernels. These failed fuel particles were detected in the chlorine leach analysis. Thus the particle failure fractions depended not on matrix-particle interaction, but the extent of zirconium reaction. As a consequence, no results were interpretable as to the effect of matrixparticle interaction.

The other half of the fuel rods in HT-26 (those from the lowtemperature regions) had no zirconium attack. The results of the chlorine leach showed acceptable particle failure fractions $(<1 \%)$ in all these rods for both the Triso and Biso particles. Because such few results were available and all were very low fractions (with greater chance for error), no difference between the annealed and unannealed partlcles ur matrix types was evident. Among the low-temperature rods, all were carbonized in graphite tubes (simulating in-block), indicating that particle failure fractions of less than $1 \%$ can be obtained from fuel rods carbonized in-tube and irradiated at temperatures up to $\sim 1090^{\circ} \mathrm{C}$ (calculated fuel centerline temperature).

\section{ACKNOWLEDGMENTS}

The authors wish to acknowledge the assistance of the following personnel of the Metals and Ceramics Division: R. A. Bradley, W. P. Eatherly, and J. D. Sease participated in the planning and design of the experiments; fuel particles were coated and characterized by C. Hamby, J. W. Geer, C. E. DeVore, R. L. Beatty, and W. J. Lackey; fue1 rod fabrication and characterization was done by R. L. Hamer, R. L. Beatty, and J. C. McLaughlin. Postirradiation metallography was performed by N. M. Atchley and L. G. Shrader; and electron microprobe analysis was done by T. J. Henson. Capsule assembly and inspection were performed by C. A. Wallace and D. L. Aubuchon of the Reactor Division. The authors also acknowledge the assistance of R. B. Parker for technical editing and Julia Bishop for typing and makeup of the report. 


\section{APPENDIX}

\section{Thermal Analysis}


THIS PAGE

WAS INTENTIONALLY

LEFT BLANK 


\section{APPENDIX}

Thermal Analysis

Design considerations called for the magazines closest to the horizontal midplane (HMP) of the reactor to operate at $1250^{\circ} \mathrm{C}$ (fuel surface temperature) and the magazines farthest from the HMP to operate at $900^{\circ} \mathrm{C}$ (fuel surface temperature). These two temperatures were to be maintained concurrently and the axial temperature profile kept as isothermal as possible in the two regions. Because of the variations of the thermal flux as a function of time and as a function of axial position, precise design conditions could not be obtained. Therefore, the design was tailored to give the desired conditions at the conclusion of 97 days or four cycles of irradiation (HT-26 and -27 ran two and four cycles respectively). That decision was due to ${ }^{235} \mathrm{U}$ burnup early in operation and the subsequent buildup of ${ }^{233} \mathrm{U}$ and ${ }^{240} \mathrm{Pu}$ from ${ }^{232} \mathrm{Th}$ and ${ }^{238} \mathrm{U}$ respectively (see Table $\mathrm{A}-1$ ).

Table A-1. Heat Generation for Various Isotopes in $\mathrm{HT}-26$ and -27

\begin{tabular}{cccc}
\hline \multirow{2}{*}{$\begin{array}{c}\text { Time } \\
\text { (days) }\end{array}$} & \begin{tabular}{c} 
Power/Mass at HMP, W/g \\
\cline { 2 - 4 } Chain
\end{tabular} & $\begin{array}{c}{ }^{23} \mathrm{~T}{ }^{8} \mathrm{U} \\
\text { Chain }\end{array}$ & $\begin{array}{c}{ }^{235} \mathrm{U} \\
\text { Chain }\end{array}$ \\
\cline { 2 - 4 } & 5.96681 & $2.3213 \times 10^{1}$ & $1.04876 \times 10^{5}$ \\
97 & $1.51648 \times 10^{3}$ & $1.90349 \times 10^{3}$ & $5.14125 \times 10^{-1}$ \\
\hline
\end{tabular}

A one-dimensional cylindrical heat transfer computer code, GENGTC, ${ }^{1}$ was performed with the neon gas gap between the graphite magazines and the containment as the only variable (desired temperatures and maximum fuel loadings were known). Consequently, the outside radius of the magazines decreases toward the center of the reactor. It should be noted that the computer code did not incorporate shrinkage of the fuel rods during irradiation. As a result, the temperatures of the fuel specimens were considerably higher than originally calculated near the termination of the irradiations.

${ }^{1}$ H. C. Roland, GENGTC, A One-Dimensional CEIR Computer Progrom for Capsule Temperature Calculations in CyZindrical Geometry, ORNL-TM-1942 (December 1967). 
The linear fission heat generation rates (LFHGR) of each of the top eight fuel rods in HT-26 and -27 are shown in Table A-2. Only the first eight rods are presented, because both capsules were considered symmetric about the HMP. The loadings in each fuel rod in all lowtemperature magazines were $0.0474 \mathrm{~g}^{232} \mathrm{Th}, 0.0015 \mathrm{~g}^{235} \mathrm{U}$, and $0.0206 \mathrm{~g}$ $2{ }^{8} \mathrm{U}$. The fuel rods in all high-temperature magazines contained $0.0662 \mathrm{~g}^{232} \mathrm{Th}, 0.0020 \mathrm{~g}^{235} \mathrm{U}$, and $0.0289 \mathrm{~g}^{238} \mathrm{U}$. Note that 47 days corresponds to the end of two HFIR cycles, and 97 days to the end of four HFIR cycles.

Table A-2. Linear Fission Heat Generation Rates vs Irradiation Time ${ }^{a}$

\begin{tabular}{|c|c|c|c|c|}
\hline \multirow{2}{*}{$\begin{array}{l}\text { Fuel Rod } \\
\text { Number }\end{array}$} & \multicolumn{4}{|c|}{$\begin{array}{c}\text { LFHGR (kW/ft) at Various Irradiation } \\
\text { Times (days) }\end{array}$} \\
\hline & 0 & 18.8 & $47^{b}$ & $97^{c}$ \\
\hline 1 & 1.201 & 0.720 & 0.800 & 0.915 \\
\hline 2 & 1.395 & 0.800 & 0.923 & 1.050 \\
\hline 3 & 1.560 & 0.873 & 1.03 & 1.170 \\
\hline 4 & 1.680 & 0.935 & 1.12 & 1.270 \\
\hline 5 & 2.53 & 1.400 & 1.71 & 1.930 \\
\hline 6 & 2.615 & 1.438 & 1.77 & 1.988 \\
\hline 7 & 2.691 & 1.473 & 1.825 & 2.040 \\
\hline 8 & 2.745 & 1.501 & 1.870 & 2.080 \\
\hline \multicolumn{5}{|c|}{ asing as-fabricated information. } \\
\hline
\end{tabular}

Table A-3 reports the temperatures at the centerline and surface of the fuel rods at various times throughout irradiation. The temperatures reported under days $0,19,47$, and 97 (as-built) assume no shrinkage of the fuel rods. The temperatures reported under day 97 (PIE) take into account radial shrinkages of the fuel rods. In particular, the shrinkages are from rods 1 to 8 in $\mathrm{HT}-27$. All of the temperature calculations do not take into account axial shrinkage, which affects the LFHGR, nor do they include the increase in the bulk fuel rod density. As shown in Table A-3, the radial shrinkage of the rods greatly affects the calculated operating temperatures, increasing them in many cases over $100^{\circ} \mathrm{C}$. 
Table A-3. Calculated Operating Temperatures at Various Times for HT-27

\begin{tabular}{|c|c|c|c|c|c|c|c|c|c|c|}
\hline \multirow{2}{*}{$\begin{array}{l}\text { Fuel Rod } \\
\text { Number }\end{array}$} & \multicolumn{5}{|c|}{ Fuel Rod Surface Temperature, ${ }^{\circ} \mathrm{C}$} & \multicolumn{5}{|c|}{ Fuel Rod Centerline Temperature, ${ }^{\circ} \mathrm{C}$} \\
\hline & Day 0 & Day 18.8 & Day 47 & $\begin{array}{c}\text { Day } 97 \\
(\text { as-built) a }\end{array}$ & $\begin{array}{l}\text { Day } 97 \\
(\mathrm{PIE})^{\mathrm{b}}\end{array}$ & Day 0 & Day 18.8 & Day 47 & $\begin{array}{c}\text { Day } 97 \\
(\text { as-built })^{a}\end{array}$ & $\begin{array}{l}\text { Day } 97 \\
(P I E)^{b}\end{array}$ \\
\hline 1 & 973 & 852 & 872 & 904 & 995 & 1051 & 908 & 932 & 969 & 1058 \\
\hline 2 & 985 & 943 & 872 & 904 & 995 & 1070 & 905 & 939 & 976 & 1066 \\
\hline 3 & 961 & 818 & 851 & 883 & 1021 & 1058 & 885 & 924 & 962 & 1098 \\
\hline 4 & 921 & 777 & 815 & 844 & 1008 & 1025 & 849 & 895 & 931 & 1092 \\
\hline 5 & 1330 & 1131 & $119 \mathrm{C}$ & 1232 & 1339 & 1476 & 1229 & 1302 & 1352 & 1457 \\
\hline 6 & 1346 & 1145 & 1207 & 1245 & 1350 & 1498 & 1246 & .1322 & 1370 & 1472 \\
\hline 7 & $134 \mathrm{C}$ & 1139 & 1204 & 1239 & 1350 & 1500 & 1243 & 1323 & 1367 & 1475 \\
\hline 8 & 1290 & 1087 & 1152 & 1185 & 1340 & 1448 & 1198 & 1273 & 1315 & 1466 \\
\hline
\end{tabular}

asing as-fabricated fuel rod dimensions.

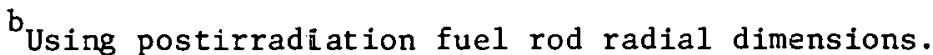


THIS PAGE

WAS INTENTIONALLY

LEFT BLANK 


\author{
ORNL/TM-5404 \\ UC-77 (Gas-Cooled \\ Reactor Technology)
}

\title{
INTERNAL DISTRIBUTION
}

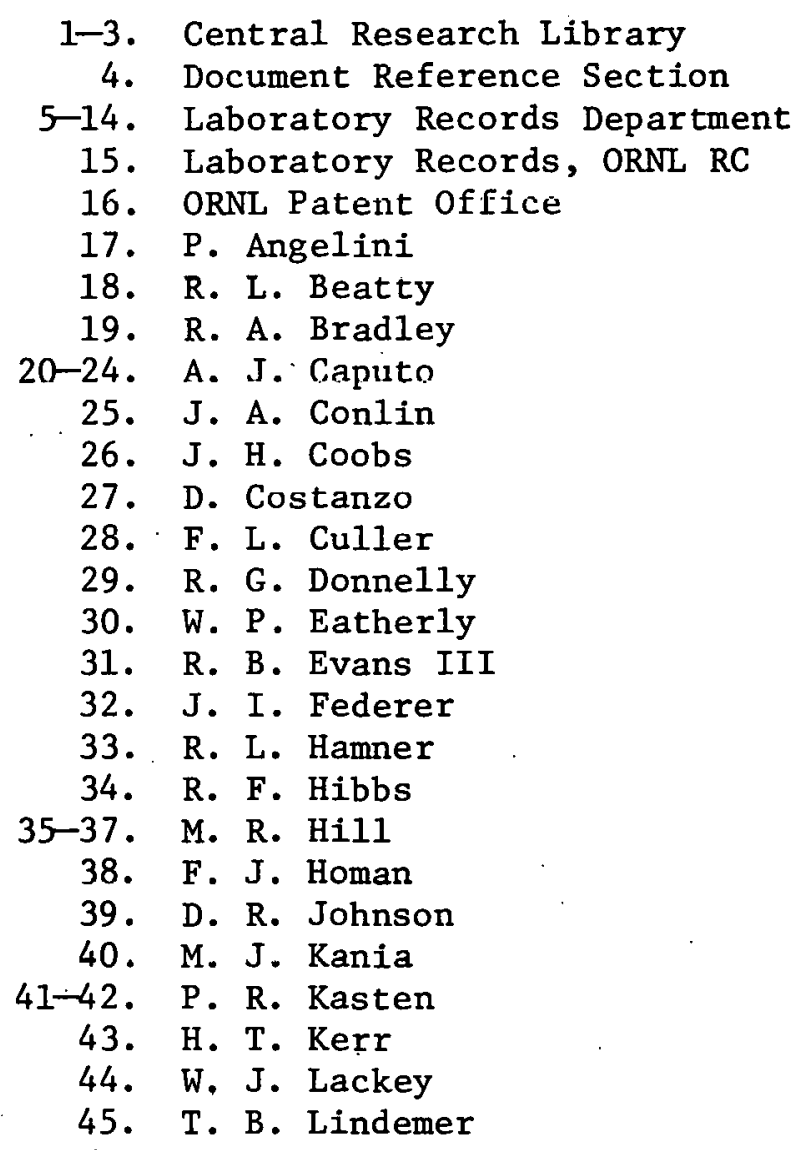
46-50. E. L. Long, Jr.
51. A. L. Lotts
52. R. E. MacPherson
53. B. H. Montgomery
54. C. S. Morgan
55. M. T. Morgan
56. K. J. Notz
57. R. L. Pearson
58. W. H. Pechin
59. H. Postma
60. W. W. Proaps
61. J M Robbins
62. J. D. Sease
63. R. L. Shepard
64. S. M. Tiegs
65-69. T. N. Tiegs
70. K. R. Thoms
71. J. E. Van Cleve, Jr.
72. G. W. Weber
73. J. R. Weir, Jr.
74. P. M. Brister (consultant)
75. John Moteff (consultant)
76. Hayne Palmour III (consultant)
77. J. W. Prados (consultant)
78. N. E. Promisel (consultant)
79. D. F. Stein (consultant)

EXTERNAL DISTRIBUTION

80-81. ERDA DIVISION OF NUCLEAR FUEL CYCLE AND PRODUCTION, Washington, DC 20545

Director

82-83. ERDA DIVISION OF NUCLEAR RESEARCH AND APPLICATION, Washington, DC 20545

Director

84-85. ERDA OAK RIDGE OPERATIONS OFFICE, P.O. BOX E, Oak Ridge, TN 37830

Director, Reactor Division

Director, Research and Technical Support Division 
EXTERNAL DISTRIBUTION (Continued)

86-252. ERDA TECHNICAL INFORMATION CENTER, Office of Information Services, P.O. Box 62, Oak Ridge, TN 37830

For distribution as shown in TID-4500 Distribution Category, UC-77 (Gas-Cooled Reactor Technology)

253-260. ERDA Exchange Agreements with Germany and Dragon Project 